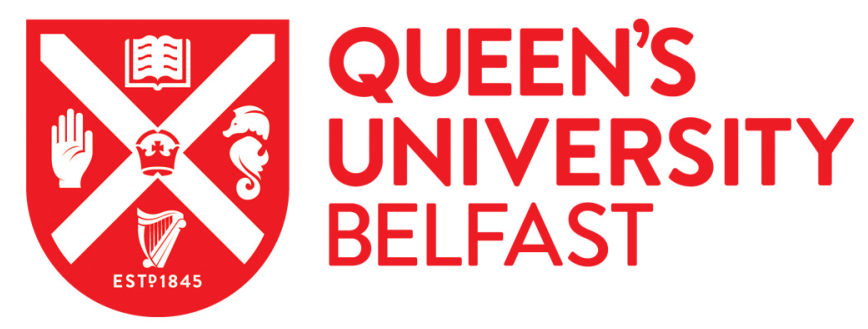

\title{
Effect of in situ temperature on the early age strength development of concretes with supplementary cementitious materials
}

Soutsos, M., Hatzitheodorou, A., Kwasny, J., \& Kanavaris, F. (2016). Effect of in situ temperature on the early age strength development of concretes with supplementary cementitious materials. Construction and Building Materials, 103, 105-116. https://doi.org/10.1016/j.conbuildmat.2015.11.034

Published in:

Construction and Building Materials

Document Version:

Peer reviewed version

Queen's University Belfast - Research Portal:

Link to publication record in Queen's University Belfast Research Portal

Publisher rights

(c) Elsevier Ltd. This manuscript version is made available under the CC-BY-NC-ND 4.0 license http://creativecommons.org/licenses/by-nc$\mathrm{nd} / 4.0$ / which permits distribution and reproduction for non-commercial purposes, provided the author and source are cited.

\section{General rights}

Copyright for the publications made accessible via the Queen's University Belfast Research Portal is retained by the author(s) and / or other copyright owners and it is a condition of accessing these publications that users recognise and abide by the legal requirements associated with these rights.

Take down policy

The Research Portal is Queen's institutional repository that provides access to Queen's research output. Every effort has been made to ensure that content in the Research Portal does not infringe any person's rights, or applicable UK laws. If you discover content in the Research Portal that you believe breaches copyright or violates any law, please contact openaccess@qub.ac.uk. 


\section{Effect of in situ temperature on the early age strength development of concretes with supplementary cementitious materials}

\section{Soutsos ${ }^{1, ~ a, ~ A . ~ H a t z i t h e o d o r o u ~}{ }^{2, b}$, J. Kwasny ${ }^{3, a}$, and F. Kanavaris ${ }^{4, a}$}

${ }^{a}$ School of Planning, Architecture and Civil Engineering, Queen's University Belfast, Belfast BT9 5AG, UK

${ }^{\mathrm{b}}$ Consultant Civil Engineer, Athens, 166 72, Greece

${ }^{1}$ m.soutsos@qub.ac.uk (* corresponding author)

2 alexengineer30@gmail.com

3 j.kwasny@qub.ac.uk

${ }^{4}$ fkanavaris01@qub.ac.uk 


\section{Highlights}

- In-situ temperature histories from blocks, walls and slabs cast during winter and summer.

- Temperature sensitivity of supplementary cementitious materials.

- Effect of supplementary cementitious materials on the peak temperature of structural members.

- Early age in-situ strength development as affected by geometry, size, ambient conditions and type of binder.

- Accuracy of maturity functions, Nurse-Saul and Arrhenius based, in estimating in-situ strength development. 


\section{Abstract}

A UK based project which involved casting of blocks, walls and slabs, during winter and summer, provided in situ temperature histories that could be simulated in the laboratory using a computer controlled temperature match curing tank. The concretes which were of 28-day target mean strengths of 50 and $30 \mathrm{MPa}$ also had partial cement replacement with supplementary cementitious materials (SCMs) such as ground granulated blast-furnace slag (GGBS) and pulverised fuel ash (PFA). The SCMs were effective in reducing the peak temperature especially when there was heat dissipation. The contribution to early age strength by SCMs increased with the high in situ temperatures especially in blocks cast during summer. The accuracy of strength estimates obtained from maturity functions was examined. The temperature dependence of the Nurse-Saul function was not sufficient to account for the improvement in early age strengths resulting from the high temperatures in blocks cast during summer. The Arrhenius based function, was better at estimating the early age strengths as it assumes that the concrete strength gain rate varies exponentially with temperature.

\section{Keywords:}

In situ temperature, Maturity functions, Strength estimates, Supplementary cementitious materials. 


\section{$1 \quad$ Introduction}

The Concrete Society in the UK carried out an investigation into the relationship between core strength and standard cured (i.e. $20^{\circ} \mathrm{C}$ ) cube strength [1], which involved casting concrete blocks, walls and slabs, see Figure 1, with mixes incorporating a wide range of cementitious materials [2]. Casting for the units for the winter phase was in February-March 1997 and continued with the summer phase in June-July 1997. The aim was to obtain data on the strength of concrete cores to assist in updating the Concrete Society Technical Report 11 (TR11) entitled "Concrete core testing for strength" which was first published in 1976 and re-published with an extensive addendum in 1987 [3]. The project had been carried out by the Concrete Society under a Partners in Technology Scheme, partly funded by the Department of Trade and Industry (DTI) - formerly the Department of Environment, Transport and the Regions (DETR). It has become known as the "DTI project" and that is how it is referred to in this paper.

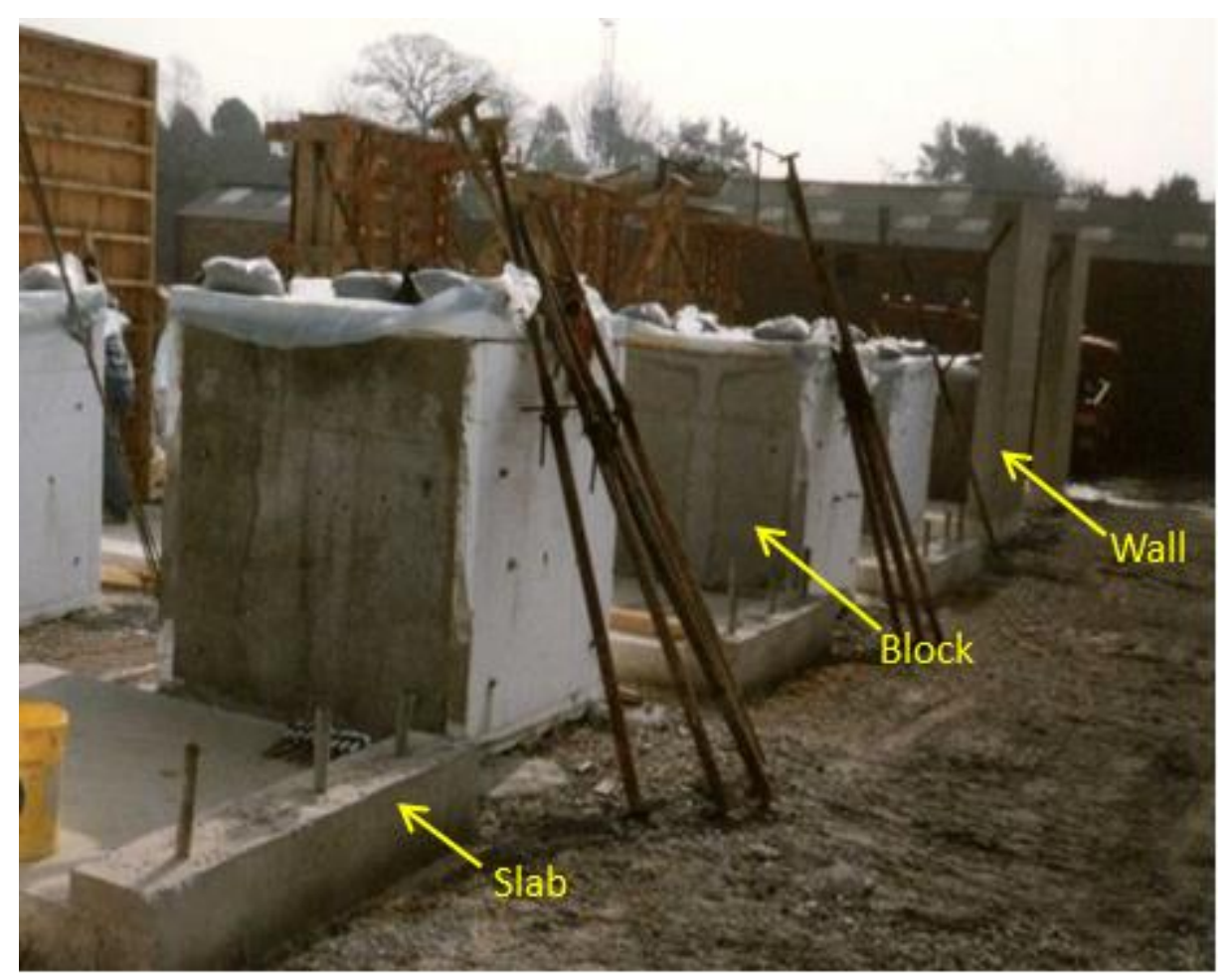

Figure 1: $\quad$ Structural elements used in the DTI project [2]. 
The project was designed to provide the information needed to enable the potential strengths of concretes with supplementary cementitious materials (SCMs) to be derived, taking into account age at test, thermal history, cement type and concrete strength. The results could then be compared with standard cured cube strengths obtained from each of the mixes. It was hoped that the difference between in situ and standard cube strength would assist in the updating of TR11 [3] and providing data so that cements not currently covered by TR11 could be included.

The data generated has been very extensive although aimed at potential strength, i.e. long-term strengths rather than early age strengths. The temperature histories obtained from the blocks, walls and slabs could be simulated in the laboratory using computer controlled temperature matched curing tanks. The aim of doing so was to determine the effect of temperature on the early age strength development of concrete mixes with SCMs. Improved compressive strengths due to higher than $20^{\circ} \mathrm{C}$ temperatures in the structural elements were expected. In order to benefit from these improved strengths, a contractor would need to be able to estimate these from the expected temperature history in a structural element. This can be achieved with maturity methods which account for the combined effect of time and temperature on the strength development of concrete [4-8].

Carino [9] has reviewed the historical development of maturity functions in great detail and only a summary of this is included here. It was proposed that the measured temperature history during the curing period could be used to compute a single number that would be indicative of the concrete strength. Saul [10] called this single factor "maturity":

$$
M=\sum_{t}\left(T-T_{0}\right) \cdot \Delta t
$$

where: $\quad \mathrm{M} \quad$ is the maturity $\left({ }^{\circ} \mathrm{C}\right.$-days), 
$\mathrm{T} \quad$ is the average temperature $\left(20^{\circ} \mathrm{C}\right.$ for standard curing $)$ over the time interval $\Delta \mathrm{t}\left({ }^{\circ} \mathrm{C}\right)$,

$\mathrm{T}_{0} \quad$ is the datum temperature $\left({ }^{\circ} \mathrm{C}\right)$,

$\Delta \mathrm{t} \quad$ is the time interval (days).

This equation has become known as the Nurse-Saul function and assumes that the rate of strength development is a linear function of temperature. It can be used to convert a given temperature-time curing history to an equivalent age of curing at a reference temperature as follows:

$$
t_{e}=\frac{\sum\left(T-T_{0}\right)}{\left(T_{r}-T_{0}\right)} \cdot \Delta t
$$

where: $\quad t_{\mathrm{e}} \quad$ is the equivalent age at the reference temperature (days),

$\mathrm{T}_{\mathrm{r}} \quad$ is the reference temperature $\left({ }^{\circ} \mathrm{C}\right)$.

Equivalent age represents the duration of the curing period at the reference temperature that would result in the same maturity as the curing period at other temperatures. The equivalent age concept, originally introduced by Rastrup [11], is a convenient method for using other functions besides Equation 1 to account for the combined effect of time and temperature on strength development. Equation 2 can be written as:

$$
t_{e}=\sum(\beta \cdot \Delta t)
$$

Equation 3

where:

$$
\beta=\frac{\left(T-T_{0}\right)}{\left(T_{r}-T_{0}\right)}
$$

The ratio $\beta$, which is called the "age conversion factor", is used to convert a curing interval $\Delta \mathrm{t}$ to the equivalent curing interval at the standard reference temperature. 
Functions described above are for calculating a maturity index (temperature-time factor or equivalent age) based on the temperature history of the concrete. Several functions have also been proposed to relate concrete strength to the maturity index [12-19]. The following S-shape function proposed by Carino [20] (Equation 4) is the one recommended in the ASTM Standard [21] procedure.

$$
S=\frac{S_{u} \cdot k \cdot\left(t-t_{0}\right)}{1+k \cdot\left(t-t_{0}\right)}
$$

\section{Equation 4}

where: $\mathrm{S}$ strength at age t, $\mathrm{MPa}$,

$\mathrm{S}_{\mathrm{u}} \quad$ ultimate strength at temperature $\mathrm{T}(\mathrm{MPa})$,

$\mathrm{k}$ the rate constant (1/days),

t test age (days),

$\mathrm{t}_{0} \quad$ age at which strength development is assumed to begin (days).

Regression analysis is needed to provide for each curing temperature the rate constant, $\mathrm{k}$, the ultimate strength, $\mathrm{S}_{\mathrm{u}}$, and the setting time, $\mathrm{t}_{0}$, of the mortar mixture.

In order to calculate the apparent activation energy, $\mathrm{E}_{\mathrm{a}}$, the ASTM Standard's recommendation [21] is to plot $\ln (\mathrm{k})$ against $1 / \mathrm{T}_{\mathrm{abs}}$ (given in $1 /$ Kelvin), where $\mathrm{T}_{\mathrm{abs}}$ is the absolute curing temperature. The slope of the trend line is equal to -Q and the activation energy $\left(E_{a}\right)$ for the mixture will be equal to $Q \cdot R$, where $R$ is the universal gas constant equal to $8.31 \mathrm{~J} / \mathrm{K} \cdot \mathrm{mol}$. The assumption that the rate of strength development obeys the Arrhenius equation leads to the maturity function (referred to as Arrhenius function in this paper):

$$
t_{e}=\sum e^{-E_{a} / R \cdot\left(\frac{1}{T_{a}}-\frac{1}{T_{s}}\right)} \cdot \Delta t
$$

Equation 5

where: $t_{e}$ the equivalent age (days),

$\mathrm{T}_{\mathrm{a}}$ average temperature of concrete during time interval $\Delta \mathrm{t}(\mathrm{K})$,

$\mathrm{T}_{\mathrm{S}} \quad$ specified reference temperature $(\mathrm{K})$, 


$$
\begin{aligned}
& \mathrm{E}_{\mathrm{a}} \text { apparent activation energy }(\mathrm{J} / \mathrm{mol}), \\
& \mathrm{R} \text { universal gas constant }(\mathrm{J} / \mathrm{K} \cdot \mathrm{mol}) \text {. }
\end{aligned}
$$

Apparent activation energies can be determined using "equivalent" mortar specimens, as described in ASTM Standard C1074-98 [21] and the results applied to the concrete under investigation. The equivalent mortars need to have the same water to binder ratios and superplasticiser dosages as the concretes. The sand to binder ratios also need to be equal to the coarse aggregate to binder ratios of the concretes. These requirements are to ensure that the strength development of the mortar specimens is similar to that of the corresponding concrete mixtures.

The aims of the work described here were therefore to:

a) Determine, using data from the DTI Core Project ${ }^{1}$, the effects of: (i) environmental conditions (summer or winter concreting), (ii) size and type of structural element (blocks, slabs and walls), (iii) concrete compressive strength (30 $\mathrm{MPa}$ and $50 \mathrm{MPa}$ ), and (iv) partial cement replacement with SCMs (pulverised fuel ash (PFA) or ground granulated blast furnace slag (GGBS) at $30 \%$ and $50 \%$ cement replacement levels, respectively) on the early age temperature history exclusively.

b) Investigate, in the laboratory using replicated mixes, the effect of particularly high early age temperatures on the in situ strength development of concrete for a selection of structural elements and concrete mixes, based on the above.

c) Assess the applicability of maturity functions, originally developed for Portland cement, for concretes containing SCMs.

The investigation was divided into 5 stages as shown in Table 1.

\footnotetext{
${ }^{1}$ Data from the DTI Core Project were provided to the authors by Dr L.K.A Sears who was directly involved with the project.
} 
Table 1: $\quad$ Outline of experimental programme.

\begin{tabular}{|c|c|c|c|c|}
\hline Stage & Objective & Investigated mixes/data & $\begin{array}{l}\text { Curing } \\
\text { condition }\end{array}$ & $\begin{array}{l}\text { Testing ages } \\
\text { for } \\
\text { compressive } \\
\text { strength }\end{array}$ \\
\hline $\begin{array}{l}\text { I } \\
\text { Determination of } \\
\text { strength vs. w/b } \\
\text { ratio relationships }\end{array}$ & $\begin{array}{l}\text { - To test several trial mixes with } \\
\text { different w/b ratios in order to replicate } \\
\text { original six mixes used in the DTI } \\
\text { project. }\end{array}$ & $\begin{array}{l}\text { Mixes with two strengths } \\
(30 \text { and } 50 \mathrm{MPa}) \\
\text { containing three binder } \\
\text { types (100\% PC, } 50 \% \\
\text { GGBS and } 30 \% \text { PFA) } \\
\text { were developed. }\end{array}$ & $\begin{array}{l}\text { Standard } \\
\text { curing } \\
\left(20^{\circ}\right)\end{array}$ & $\begin{array}{l}7 \text { and } 28 \\
\text { days }(100 \\
\text { mm cubes })\end{array}$ \\
\hline $\begin{array}{l}\text { II } \\
\text { Replication of } \\
\text { concrete mixes } \\
\text { used in the DTI } \\
\text { project }\end{array}$ & $\begin{array}{l}\text { - To investigate, under laboratory } \\
\text { conditions, the strength development of } \\
\text { selected replicates mixes of the DTI } \\
\text { project } \\
\text { - To compare their strength } \\
\text { development with those of mixes from } \\
\text { the DTI project }\end{array}$ & $\begin{array}{l}\text { PC30 and PC50 } \\
\text { GGBS30 and GGBS50 } \\
\text { PFA30 and PFA50 }\end{array}$ & $\begin{array}{l}\text { Standard } \\
\text { curing } \\
\left(20^{\circ}\right)\end{array}$ & $\begin{array}{l}1,2,3,5,7 \\
14,28,42 \\
84,156 \text { and } \\
365 \text { days } \\
\text { (100 mm } \\
\text { cubes })\end{array}$ \\
\hline $\begin{array}{l}\text { III } \\
\text { Effect of size and } \\
\text { ambient conditions } \\
\text { on temperature } \\
\text { histories }\end{array}$ & $\begin{array}{l}\text { - To analyse the original DTI project } \\
\text { data in order to determine the effect of } \\
\text { size (slab, block, wall and slab) and } \\
\text { ambient conditions (summer and } \\
\text { winter) on temperature history recorded } \\
\text { in cast elements. }\end{array}$ & $\begin{array}{l}\text { Temperature data from the } \\
\text { DTI project } \\
\text { PC30 and PC50 } \\
\text { GGBS30 and GGBS50 } \\
\text { PFA30 and PFA50 }\end{array}$ & $\begin{array}{l}\text { Ambient } \\
\text { conditions } \\
\text { (summer } \\
\text { and winter) }\end{array}$ & - \\
\hline $\begin{array}{c}\text { IV } \\
\text { Effect of } \\
\text { temperature on } \\
\text { strength } \\
\text { development } \\
\end{array}$ & $\begin{array}{l}\text { - To investigate the effect of } \\
\text { temperature history (selected from } \\
\text { Stage } \text { III) on the strength development } \\
\text { of investigated concrete mixes (from } \\
\text { Stage II). }\end{array}$ & \multirow[b]{2}{*}{$\begin{array}{l}\text { PC30 and PC50 } \\
\text { GGBS30 and GGBS50 } \\
\text { PFA30 and PFA50 }\end{array}$} & \multirow{2}{*}{$\begin{array}{l}\text { Temperature } \\
\text { matched } \\
(\mathrm{TMC}) \text { and } \\
\text { standard ( } 20 \\
\left.{ }^{\circ} \mathrm{C}\right) \text { curing }\end{array}$} & \multirow[b]{2}{*}{$\begin{array}{c}1,2,3,5,7 \\
14,28 \text { and } \\
42, \text { days }(100 \\
\text { mm cubes) }\end{array}$} \\
\hline $\begin{array}{c}\text { IV } \\
\text { Applicability/ } \\
\text { accuracy of } \\
\text { maturity methods } \\
\text { for estimating the } \\
\text { in situ strength } \\
\text { development of } \\
\text { mixes with SCMs }\end{array}$ & $\begin{array}{l}\text { - To assess the applicability } \\
\text { of the Nurse-Saul and Arrhenius } \\
\text { maturity functions for estimating the in } \\
\text { situ strength development of mixes with } \\
\text { SCMs using experimental data from } \\
\text { Stage IV. }\end{array}$ & & & \\
\hline
\end{tabular}

\section{$2 \quad$ Materials and experimental procedures}

\subsection{Materials}

The objective was to use cement, SCMs and aggregates that were as similar as possible to those used for the original DTI project.

Portland cement (PC), conforming to requirements of BS EN 197-1:2000 [22] and having a 28-day compressive strength of $57 \mathrm{MPa}$ (tested according to the method described in BS EN 196-1-2005 [23]), was supplied in bags by British Lime Industries. 
It is important to note that British Lime Industries was also the supplier of the cement for the DTI project. A slight variation in the cement composition may have however existed since this research project started years after the DTI project had been completed. PC was partially replaced with ground granulated blast furnace slag (GGBS) and pulverised fuel ash (PFA) conforming to BS EN 15167-1:2006 [24] and BS EN 450-1:2005 [25], respectively. GGBS was supplied in bags by the Appleby Group whereas PFA was supplied in sealed plastic buckets by Fiddlers Ferry, a coalfired electricity-generating station, in Warrington, UK. The chemical composition of PC, GGBS and PFA are shown in Table 2.

Table 2: $\quad$ Chemical composition of $P C, G G B S$ and PFA.

\begin{tabular}{|c|c|c|c|}
\hline \multicolumn{4}{|c|}{ Chemical Composition } \\
\hline \multirow{2}{*}{$\begin{array}{l}\text { Chemical } \\
\text { Constituent }\end{array}$} & PC & GGBS & PFA \\
\hline & \multicolumn{3}{|c|}{ \% by weight of dry mass } \\
\hline $\mathrm{SiO}_{2}$ & 20.11 & 35.35 & $38-52$ \\
\hline $\mathrm{Al}_{2} \mathrm{O}_{3}$ & 5.16 & 14 & $20-40$ \\
\hline $\mathrm{Fe}_{2} \mathrm{O}_{3}$ & 3.14 & 0.36 & $6-16$ \\
\hline $\mathrm{CaO}$ & 65.49 & 41.41 & $1.8-10$ \\
\hline $\mathrm{MgO}$ & 0.8 & 7.45 & $1.0-3.5$ \\
\hline $\mathrm{SO}_{3}$ & 3.22 & 0.1 & $0.35-2.5$ \\
\hline $\mathrm{K}_{2} \mathrm{O}$ & 0.59 & - & $2.3-4.5$ \\
\hline $\mathrm{Na}_{2} \mathrm{O}$ & 0.13 & - & $0.8-1.8$ \\
\hline $\mathrm{CaCO}_{3}$ & 4.47 & - & - \\
\hline $\begin{array}{l}\text { Equiv. Alks } \\
\mathrm{Na}_{2} \mathrm{Oe}\end{array}$ & 0.52 & - & - \\
\hline Free Lime & 1.79 & - & - \\
\hline Chloride & $71 \mathrm{ppm}$ & - & - \\
\hline
\end{tabular}

The coarse aggregate initially used was 5-20 mm uncrushed round gravel from the Fagl Lane quarry, which is located in Wales. Its specific gravity and water absorption were 2.64 and $1.7 \%$, respectively. The coarse aggregate had to be changed for later experiments, e.g., for temperature matched curing (TMC). A 5-20 mm well graded uncrushed round gravel was obtained from the Borras quarry, also located in Wales. This type of gravel was similar to that from Fagl Lane. The specific gravity and water absorption of the Borras gravel were 2.60 and $2.4 \%$, respectively. The grading curves 
for the Fagl Lane gravel and Borras gravel are shown in Figure 2, as are also shown overall grading limits from BS882:1992 [26]

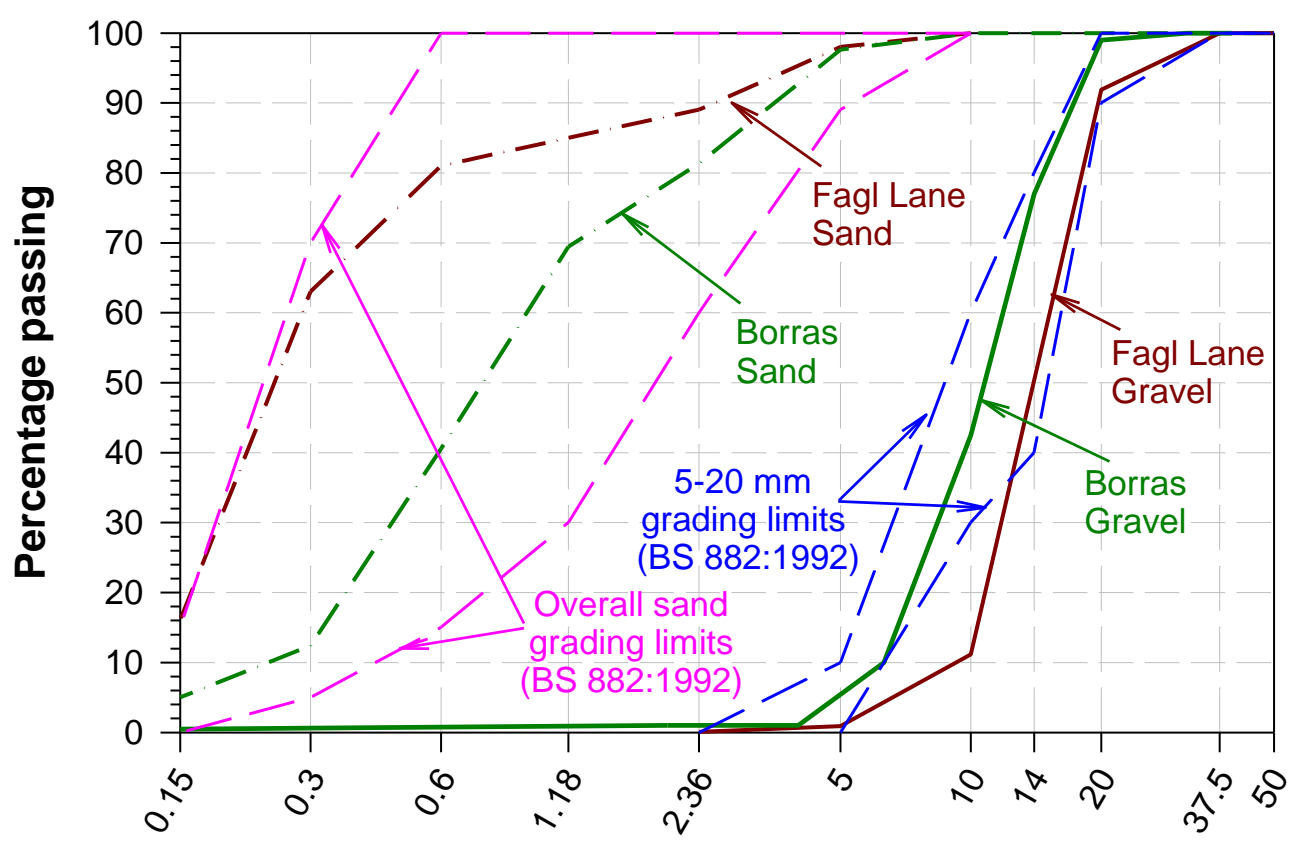

Nominal sieve size $(\mathrm{mm})$

Figure 2: $\quad$ Sieve analysis of coarse and fine aggregates.

The fine aggregate used initially for the trial mixes and standard $\left(20^{\circ} \mathrm{C}\right)$ cured concrete mixes was well graded fine aggregate obtained from the Fagl Lane quarry having specific gravity of 2.60 and water absorption of $2.6 \%$. Fine aggregate for the remaining experimental work was sourced from the Borras quarry, and it was found to be significantly coarser but better graded than the Fagl Lane sand (see Figure 2). The specific gravity and water absorption of the Borras sand were 2.40 and $0.9 \%$, respectively.

The change in the aggregate source became necessary as a result of the closure of the Fagl Lane quarry during the project. The aggregates from the Borras quarry were found not to affect significantly the workability and had insignificant effect on the strength development of the previously developed concrete mixes. Therefore, no changes to the mix proportions were required. 


\subsection{Mixing, casting, curing and testing procedures}

All concrete mixes were batched using a $0.1 \mathrm{~m}^{3}$ capacity horizontal pan mixer. Binder and aggregate were placed first in the mixing pan and dry-mixed for one minute. Water was then added and mixing continued for a further five minutes. The workability was assessed by carrying out the slump test according to BS EN 12350-2:2000 [27]. Concrete cube specimens (100 mm size) were subsequently cast in two layers in singleand three-gang steel moulds, and each layer was compacted using a vibrating table.

Two different curing procedures were used:

- Standard curing for which the concrete specimens, inside single cube moulds, were covered with wet hessian and a polythene sheet and cured under room temperature conditions (approximately $20^{\circ} \mathrm{C}$ ). They were demoulded at 24 hours after casting, and placed inside a water bath set at $20{ }^{\circ} \mathrm{C}$.

- Temperature match curing (TMC) - The concrete specimens, inside threegang moulds, were sealed using a cling film and a tape and placed inside programmable computer controlled water tanks. They were cured under TMC conditions using temperature histories recorded during the DTI project. A programmable computer controlled water tank shown in Figure 3 was used to simulate the in situ temperature histories. The cling film was removed at 24 hours after casting, but the cubes were placed back to the tank until they were tested.

Three $100 \mathrm{~mm}$ concrete cubes were used for determining the compressive strength according to BS EN 12390-3:2002 [1]. Compressive strength was determined at testing ages as shown in Table 1. 


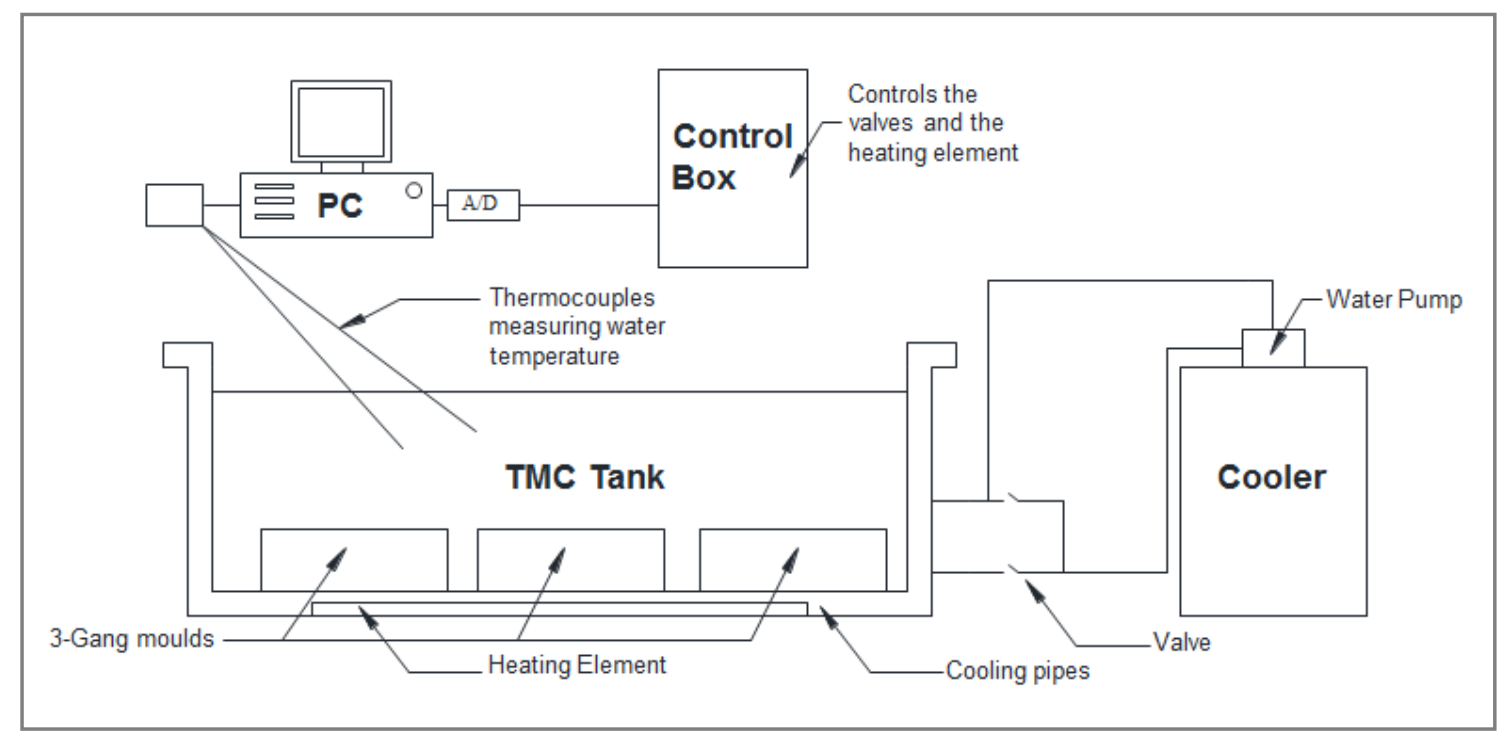

Figure 3: $\quad$ Programmable computer controlled water tank for in-situ temperature history simulations

\section{$3 \quad$ Results and discussion}

\subsection{Determination of strength versus $w / b$ ratio relationships}

The aim was to replicate in the laboratory the concrete mixes used in the DTI project. The cement and SCMs were obtained from the same suppliers but several years after the DTI project had been completed. Therefore, some variation in chemical composition and physical properties were expected. Sand and coarse aggregate were from different quarries. As such some preliminary studies were needed to determine concrete mixes with the same binder content and 28-day compressive strength even if the water to binder $(\mathrm{w} / \mathrm{b})$ ratio had to be changed slightly. The best way of achieving this was to first determine strength versus w/b ratio relationships for Portland cement mixes and for mixes with partial cement replacements with GGBS and PFA of $50 \%$ and $30 \%$, respectively. These are shown in Figure 4, as are strength curves used in the BRE mix design [28]. 


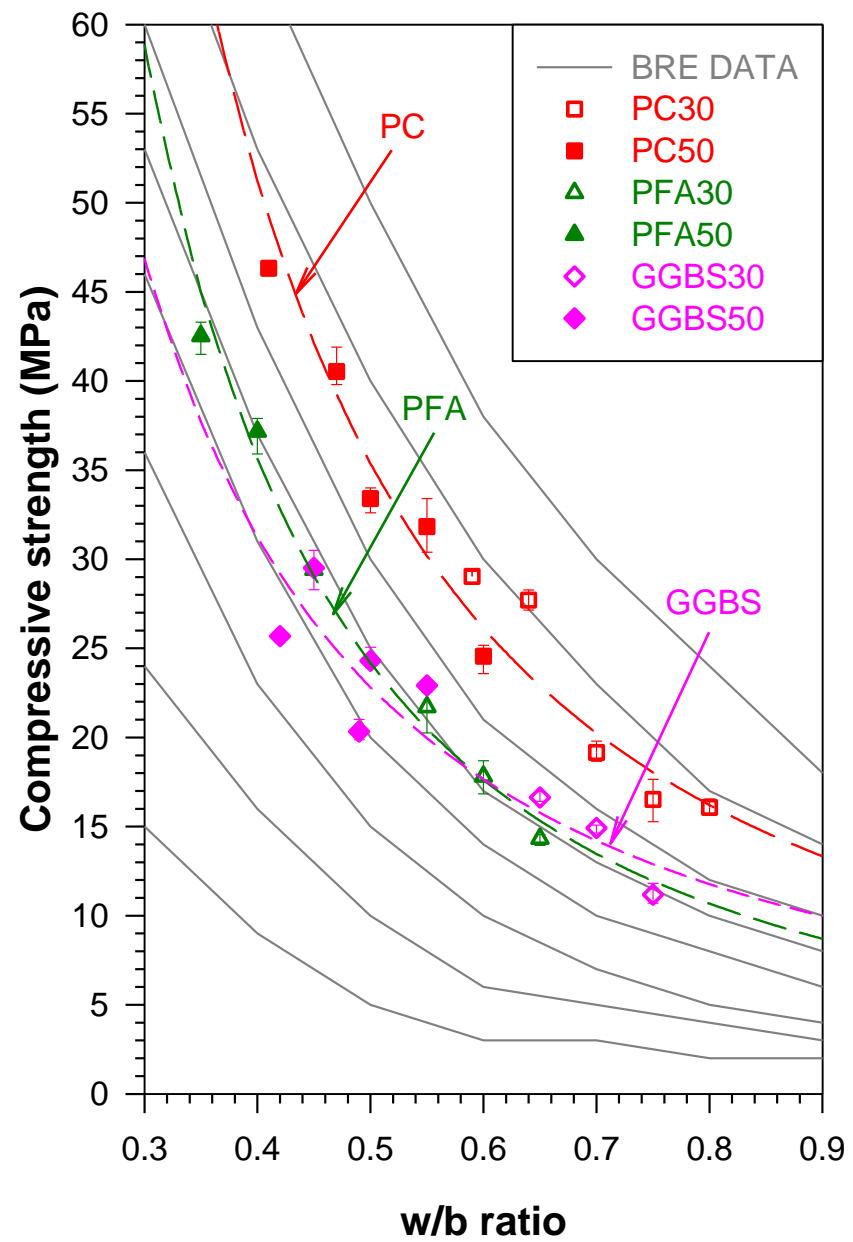

a) 7-day

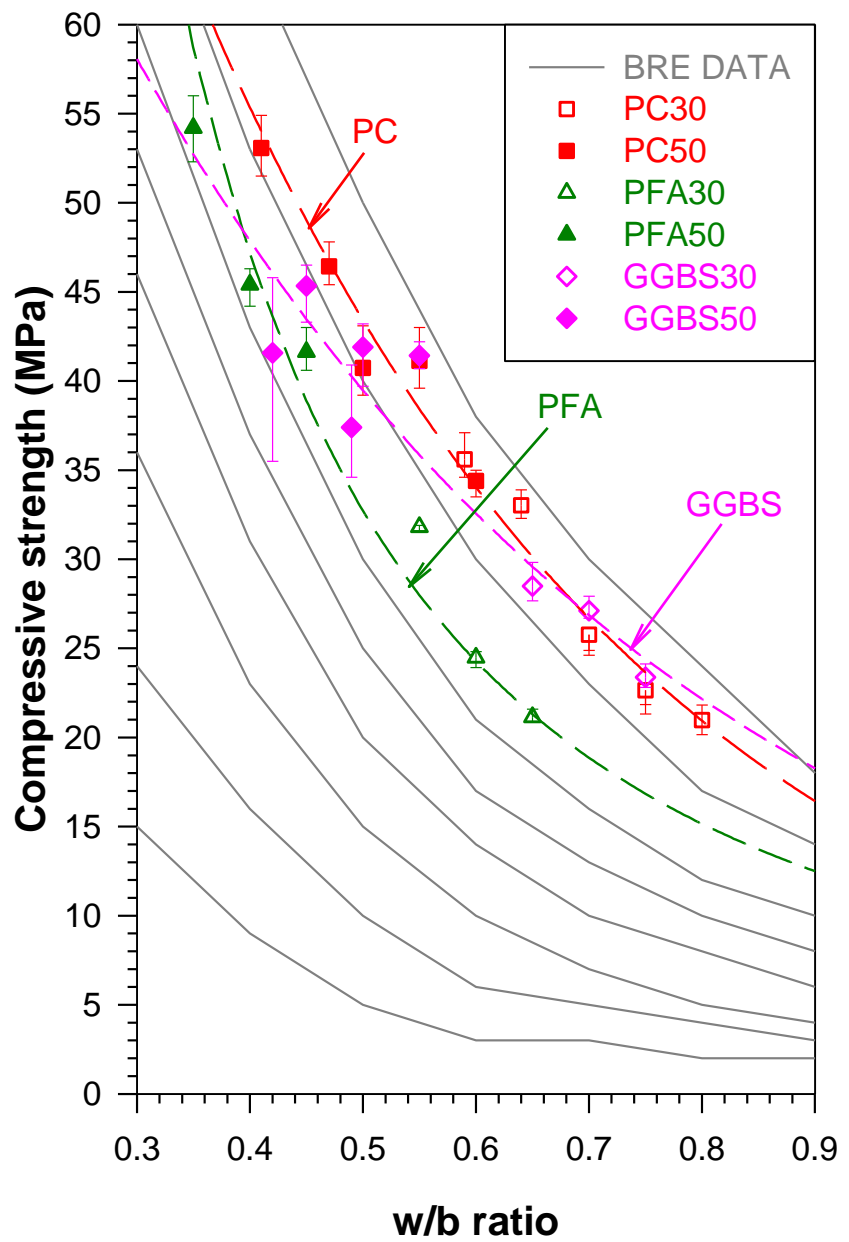

b) 28-day

Figure 4: $\quad$ Compressive strength versus w/b ratio for laboratory trial mixes. 
PC and GGBS concrete strength versus w/b ratio relationships are very similar at 28days and as such their w/b ratios for target mean strengths of $30 \mathrm{MPa}$ and $50 \mathrm{MPa}$ are also similar (as can be seen from Table 3). PFA mixes however require a lower w/b ratio to achieve the same strength as PC mixes. It is interesting to note that the strength versus $w / b$ ratio relationships for PFA and GGBS mixes are distinctly lower than that of PC mixes at 7-days. This clearly shows that the GGBS and PFA mixes have lower compressive strengths at early ages despite having the same 28-day strength as PC mixes. There is also some indication that the contribution of GGBS to strength is affected by lower w/b ratios. The slopes of the relationships are different for GGBS as compared to the PC and PFA ones. This difference is again more pronounced at 7-days with only a small indication of this effect at 28-days.

Table 3: $\quad$ Mix proportions of concrete mixes used in the DTI project and their laboratory replicates.

\begin{tabular}{|c|c|c|c|c|c|c|c|c|c|c|c|c|}
\hline Mix ID & \multicolumn{2}{|c|}{ PC30 } & \multicolumn{2}{|c|}{ GGBS30 } & \multicolumn{2}{|c|}{ PFA30 } & \multicolumn{2}{|c|}{ PC50 } & \multicolumn{2}{|c|}{ GGBS50 } & \multicolumn{2}{|c|}{ PFA50 } \\
\hline Material & 尊 & 泀 & 尊 & 䔍 & 尝 & 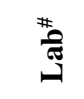 & 葛 & 泀 & 尊 & 帮 & 尊 & 畉 \\
\hline $\begin{array}{l}\text { Cement } \\
{\left[\mathrm{kg} / \mathrm{m}^{3}\right]}\end{array}$ & 240 & 240 & 115 & 115 & 193 & 193 & 345 & 345 & 165 & 165 & 270 & 270 \\
\hline $\begin{array}{l}\text { GGBS } \\
{\left[\mathrm{kg} / \mathrm{m}^{3}\right]}\end{array}$ & - & - & 115 & 115 & - & - & - & - & 165 & 165 & - & - \\
\hline $\begin{array}{l}\text { PFA } \\
{\left[\mathrm{kg} / \mathrm{m}^{3}\right]}\end{array}$ & - & - & - & - & 82 & 82 & - & - & - & - & 115 & 115 \\
\hline $\begin{array}{l}\text { Gravel } \\
{\left[\mathrm{kg} / \mathrm{m}^{3}\right]}\end{array}$ & 1246 & 1102 & 1243 & 1187 & 1253 & 1319 & 1258 & 1205 & 1258 & 1151 & 1256 & 1250 \\
\hline $\begin{array}{l}\text { Sand } \\
{\left[\mathrm{kg} / \mathrm{m}^{3}\right]}\end{array}$ & 695 & 799 & 705 & 721 & 663 & 560 & 599 & 615 & 613 & 683 & 562 & 533 \\
\hline $\begin{array}{l}\text { Free water } \\
{\left[\mathrm{kg} / \mathrm{m}^{3}\right]}\end{array}$ & - & 158 & - & 150 & - & 144 & - & 160 & - & 165 & - & 135 \\
\hline $\begin{array}{l}\text { Total water } \\
{\left[\mathrm{kg} / \mathrm{m}^{3}\right]}\end{array}$ & 189 & 198 & 190 & 190 & 174 & 181 & 185 & 197 & 184 & 203 & 175 & 171 \\
\hline Free w/b & - & 0.66 & - & 0.65 & - & 0.52 & - & 0.46 & - & 0.50 & - & 0.35 \\
\hline Total w/b & 0.79 & 0.83 & 0.83 & 0.82 & 0.63 & 0.66 & 0.54 & 0.57 & 0.56 & 0.61 & 0.45 & 0.44 \\
\hline
\end{tabular}




\subsection{Replication of DTI concrete mixes}

Mix proportions used for the DTI project and those that gave similar 28-day strength in the laboratory are shown in Table 3. Replication of the DTI project mixes did however require not only the 28-day strength but also the early age concrete strength development to be similar. Compressive strengths from the DTI project were only available from 7-days onwards and thus the need to replicate them in the laboratory to obtain early age data, i.e. 1-day onward.

The strength development of the DTI project mixes and of the laboratory replicate mixes is shown in Figure 5. Similar strengths at 7 and 14-days were obtained. Some slight difference in average value was expected but this was within the error region of the strengths from the DTI project. The same applied for long term strengths which were monitored up to 365-days.

The strength development curves for all the six replicated mixes, i.e. PC30 and PC50, GGBS30 and GGBS50, and PFA30 and PFA50, are shown in Figure 6(a) whilst the Sshape function proposed by Carino [20] (Eq. (4)), which is also the one recommended by ASTM Standard [21], was used for the regression curves. It does appear that PFA30 and PFA50 concretes had 28-day compressive strengths that were higher than those of the corresponding PC and GGBS mixes. The figure also shows PFA's long term contribution to compressive strength development. The early age compressive strength of GGBS mixes is again confirmed to be lower than the equivalent ones of PC and even PFA mixes. Figure 6(b) shows the compressive strength versus maturity index as calculated by Equation 1. 


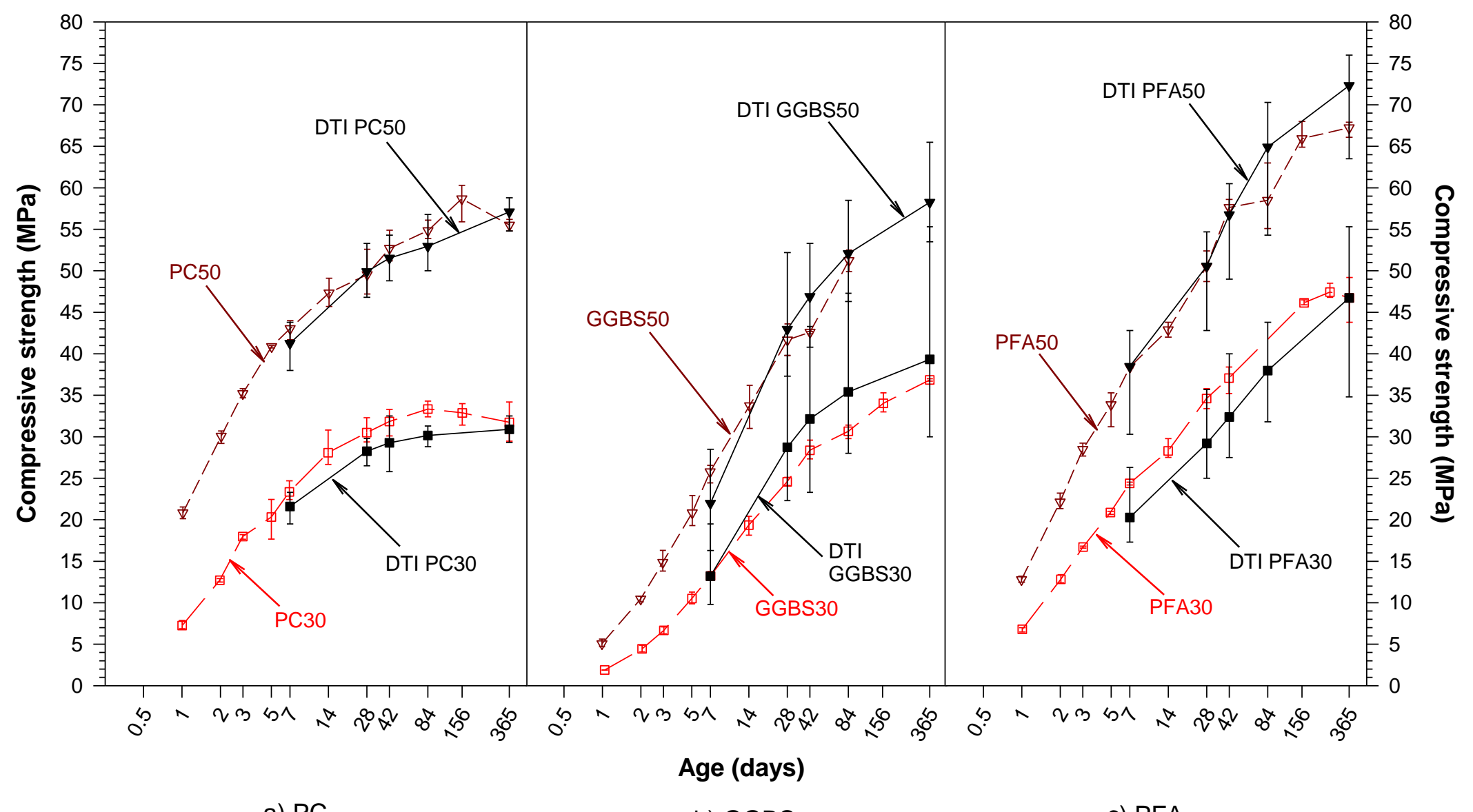
a) PC
b) GGBS
c) PFA

Figure 5: $\quad$ Comparison of the strength development of DTI and laboratory replicated DTI concrete mixes (standard $20^{\circ} \mathrm{C}$ curing). 


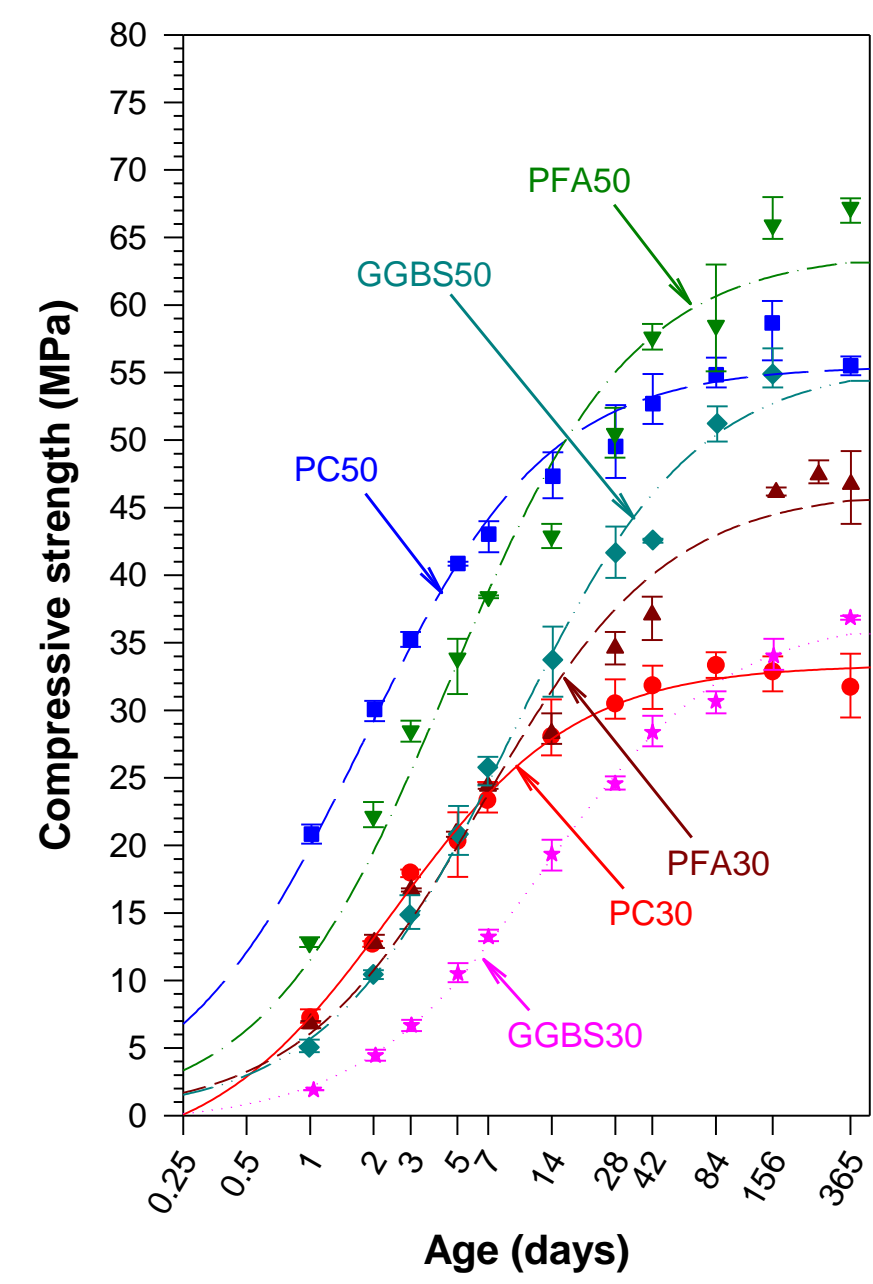

a) Strength vs Age

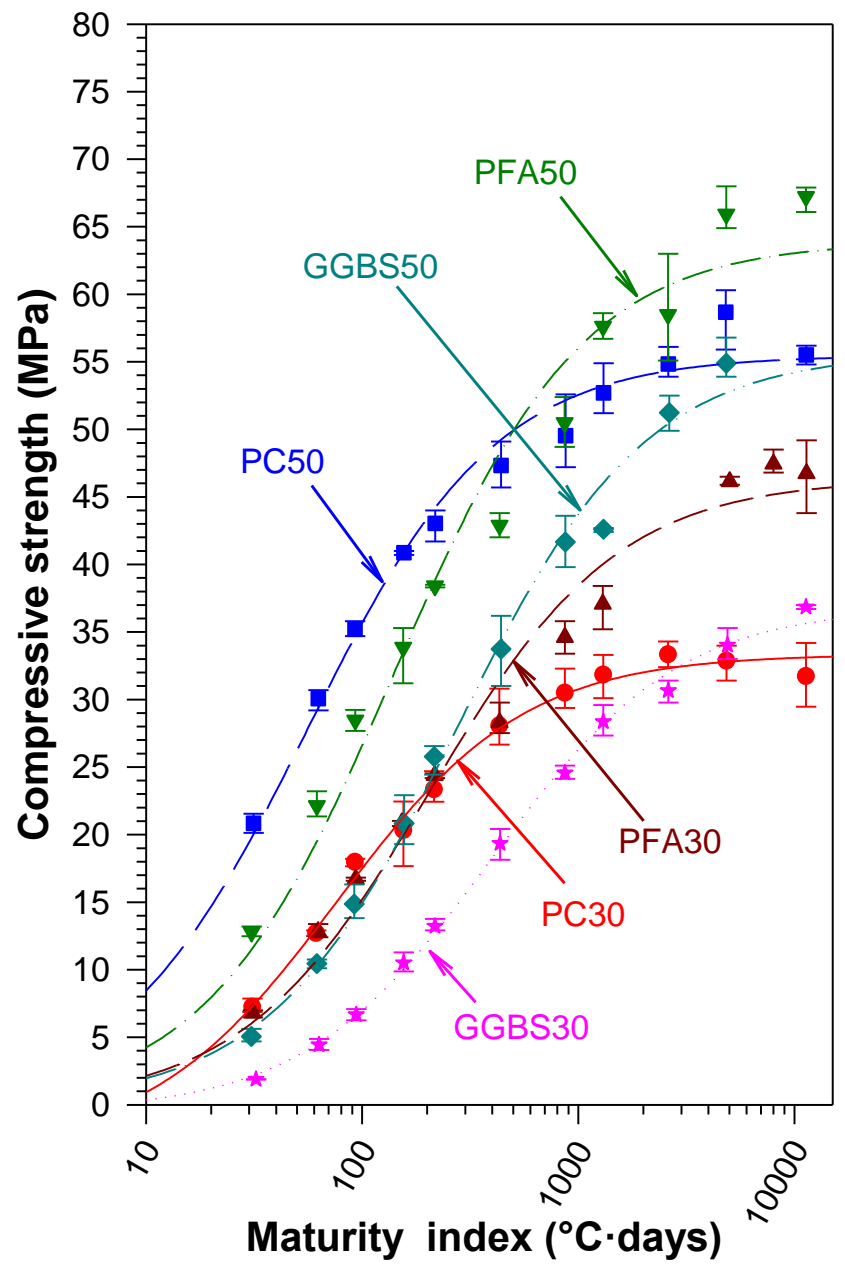

b) Strength vs Maturity index

Figure 6: $\quad$ Strength development regression analysis plots of laboratory replicated DTI concrete mixes (standard $20{ }^{\circ} \mathrm{C}$ curing). 


\subsection{Effect of size (block, wall or slab) and ambient conditions (winter/summer) on temperature histories - the DTI Concrete Core Project}

The temperature readings from the DTI project were very extensive; one hundred and sixty thermocouples were read every four hours in the first phase of the project and every hour in the second phase. The data from thermocouples placed in the centre of the blocks, walls ( $1.1 \mathrm{~m}$ height from the base and $0.4 \mathrm{~m}$ from the edge) and slab ( $0.5 \mathrm{~m}$ from the edges) are only reported here. Ambient temperatures were also recorded. Peak temperatures and the time when this occurred are shown in Table 3.

Table 4: Peak temperature and time when this occurred.

\begin{tabular}{|c|c|c|c|c|c|c|c|c|c|c|c|c|c|}
\hline \multirow[b]{2}{*}{ : } & \multirow{2}{*}{\begin{tabular}{l}
\multicolumn{1}{c}{ Mix ID } \\
\\
Curing \\
condition
\end{tabular}} & \multicolumn{2}{|c|}{ PC30 } & \multicolumn{2}{|c|}{ GGBS30 } & \multicolumn{2}{|c|}{ PFA30 } & \multicolumn{2}{|c|}{ PC50 } & \multicolumn{2}{|c|}{ GGBS50 } & \multicolumn{2}{|c|}{ PFA50 } \\
\hline & & 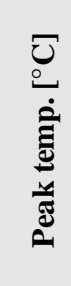 & 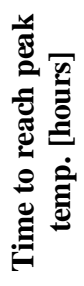 & 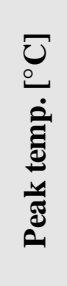 & 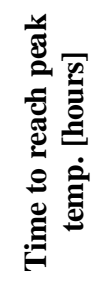 & 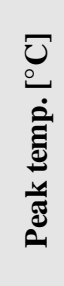 & 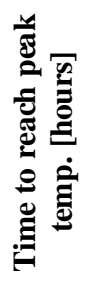 & 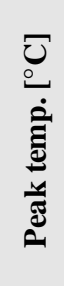 & 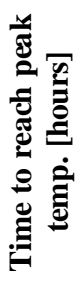 & 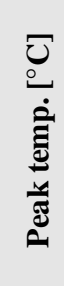 & 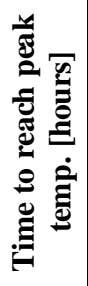 & 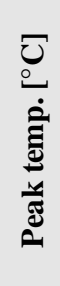 & 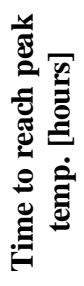 \\
\hline \multirow{2}{*}{ 믐 } & Summer & 54 & 33 & 56 & 47 & 50 & 43 & 61 & 33 & 51 & 60 & 56 & 48 \\
\hline & Winter & 44 & 31 & 26 & 60 & 37 & 52 & 58 & 33 & 39 & 72 & 50 & 43 \\
\hline \multirow{2}{*}{ 宗 } & Summer & 32 & 13 & 24 & 13 & 28 & 15 & 41 & 13 & 28 & 15 & 35 & 15 \\
\hline & Winter & 22 & 24 & 15 & 29 & 20 & 29 & 30 & 20 & 18 & 32 & 26 & 24 \\
\hline \multirow{2}{*}{ की } & Summer & 29 & 8 & 28 & 6 & 28 & 7 & 27 & 10 & 22 & 27 & 27 & 28 \\
\hline & Winter & 11 & 20 & 9 & 24 & 11 & 12 & 11 & 28 & 9 & 29 & 11 & 32 \\
\hline
\end{tabular}

Peak temperatures in blocks cast during summer reached as high as $61{ }^{\circ} \mathrm{C}$ for the PC50 concrete (see Figure 7a and Table 4). It must be noted that these blocks, despite of their size (cubes with size of $1.5 \mathrm{~m}$ ) were also insulated $(100 \mathrm{~mm}$ thick recycled expanded polystyrene sheets insulated all but one of the cube faces) in order to simulate as much as possible mass concrete pours. As such it appears that the heat dissipation during summer conditions was small, which helped increase the temperature inside the blocks. These must have accelerated the pozzolanic reaction, with GGBS50 and PFA50 mixes reaching temperatures of $51{ }^{\circ} \mathrm{C}$ and $56^{\circ} \mathrm{C}$, respectively. These are relatively small 
reductions in peak temperature; $10{ }^{\circ} \mathrm{C}$ and $5{ }^{\circ} \mathrm{C}$ lower for GGBS and PFA mixes respectively from the $61{ }^{\circ} \mathrm{C}$ of PC50. Considerably higher temperature reductions were obtained for blocks cast during winter (see Figure 7b) indicating that perhaps "mass concrete pour" conditions were not fully achieved despite the use of insulating materials. GGBS50 and PFA50 concrete block cast during winter reached their peak temperatures at 72 and 43 hours respectively, as compared to 33 hours for PC50 and this has allowed more time for heat dissipation to occur. The reductions were more significant for the lower strength concrete of $30 \mathrm{MPa}$, as can be seen from Figure 8. It can be concluded that, when there is heat dissipation the SCMs are effective in reducing the peak temperatures arising from heat of hydration in structural and mass concrete elements.

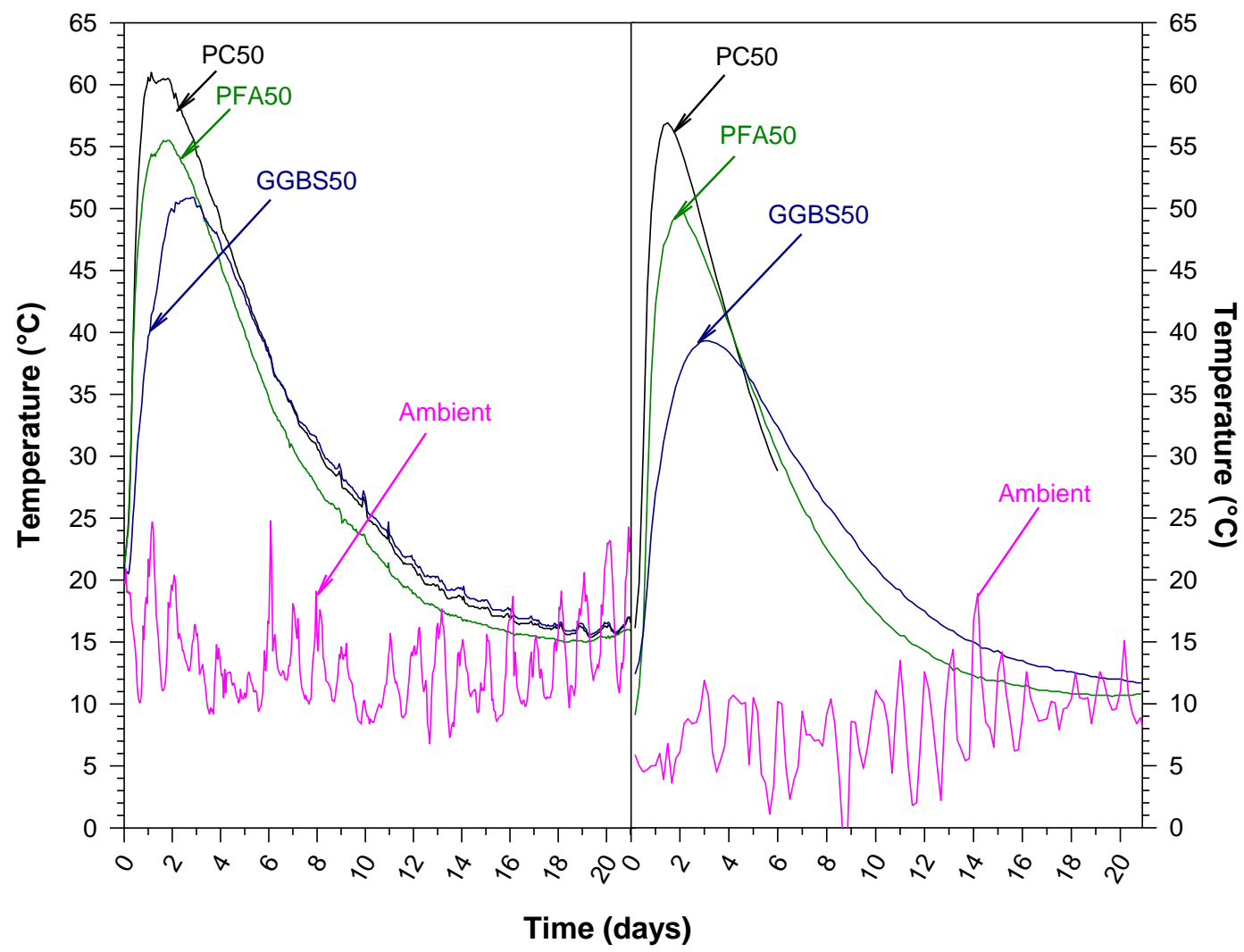
a) Summer
b) Winter

Figure 7: $\quad$ In situ recorded temperature histories for blocks made with $50 \mathrm{MPa}$ strength concretes [2]. 


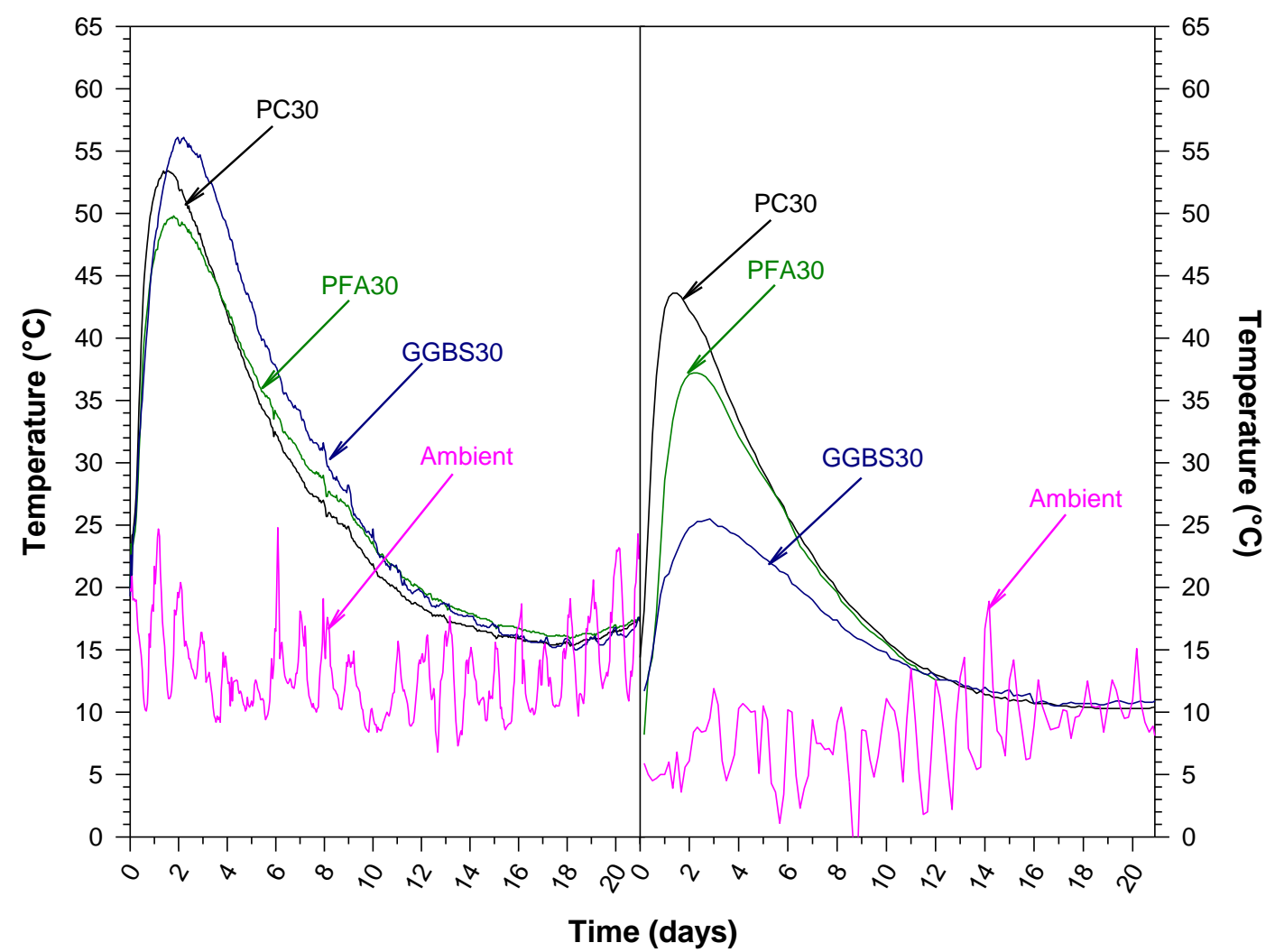

a) Summer

b) Winter

Figure 8: $\quad$ In situ recorded temperature histories for blocks made with $30 \mathrm{MPa}$ strength concretes [2].

The peak temperatures in the walls cast during summer were only $41^{\circ} \mathrm{C}, 28^{\circ} \mathrm{C}$ and $35^{\circ} \mathrm{C}$ for PC, GGBS and PFA concretes of strength $50 \mathrm{MPa}$ (see Figure 9). These were even lower when the walls were cast during winter with an average ambient temperature of around $8{ }^{\circ} \mathrm{C}$ as compared to $15^{\circ} \mathrm{C}$ for summer. The temperatures inside walls also very quickly dropped to the ambient temperature, i.e. within 2 days after concrete was cast. In comparison, blocks required 18 days in summer and 14 days in winter for their temperature to drop to ambient (Figure 7 and 8). Temperatures within the walls subsequently followed, within a bit of delay, the diurnal ambient temperature. This was related to their geometry, size and lack of insulation. 


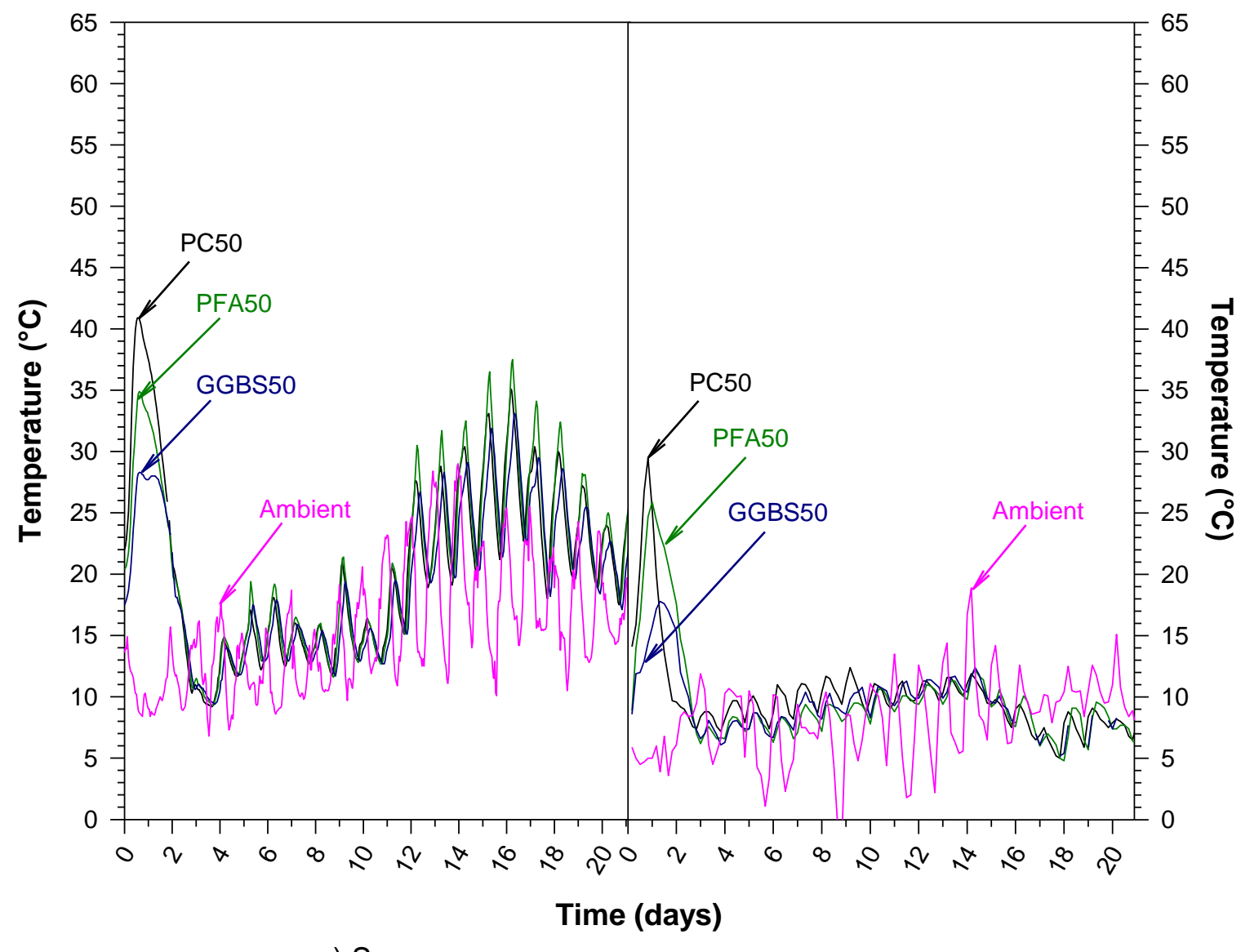

a) Summer

b) Winter

Figure 9: $\quad$ In situ recorded temperature histories for walls made with $50 \mathrm{MPa}$ strength concretes [2].

There was no distinct/identifiable peak temperature in slabs, see Figure 10. The heat dissipation must have been high so that their internal temperature dropped quickly to and followed closely the diurnal ambient temperature. 


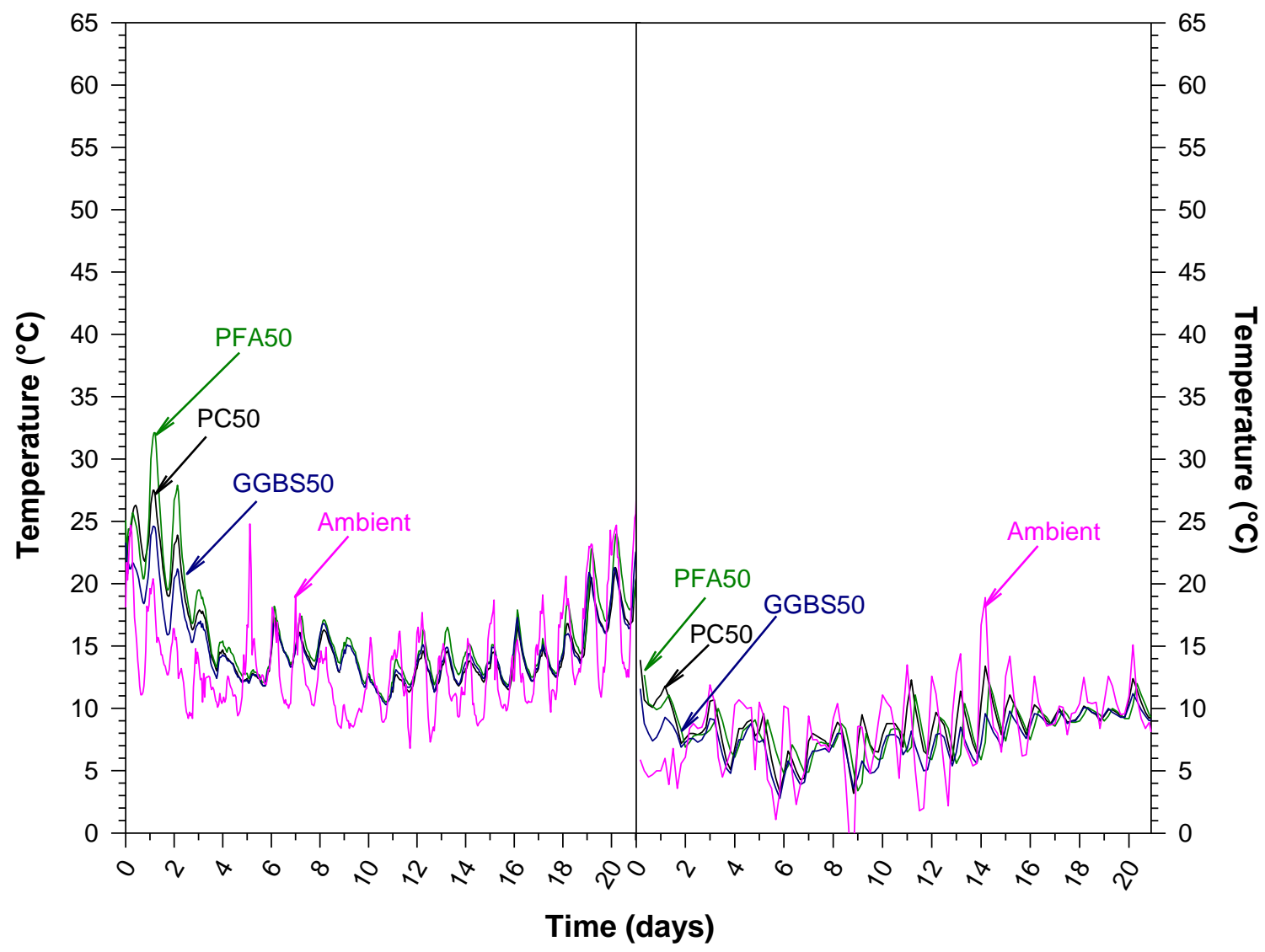

a) Summer

b) Winter

Figure 10: $\quad$ In situ recorded temperature histories for slabs made with $50 \mathrm{MPa}$ strength concretes [2].

\subsection{Effect of in situ temperature histories on strength development - laboratory based work}

The main aim of this work was to investigate the beneficial effect of high early age temperature on the contribution of SCMs to the early age concrete strength development. As such the temperature histories simulated with the computer controlled TMC tanks were those of blocks cast during summer. Mixes of 28-day strength of 50 MPa were investigated for PC, GGBS and PFA. Only the PC of 28-day strength of 30 $\mathrm{MPa}$ was investigated for block cast during summer. No blocks cast during winter were simulated in the laboratory. Peak temperatures in walls reached $41^{\circ} \mathrm{C}$ during 
summer casting, but these higher than ambient temperatures only lasted up till three days. Nonetheless, the walls cast during summer and of 28-day strength of $50 \mathrm{MPa}$ (PC50, GGBS50 and PFA50) were simulated in the laboratory to quantify the beneficial effect of these high early age temperatures of shorter duration than those of the blocks. No slabs were simulated as there were no significant temperature rises in them.

The high early age temperatures inside the block were beneficial in increasing the early age concrete strength of the PC50 mix from day one and this continued up till fourteen days (see Figure 11a). However, the high early age temperature has a detrimental effect on the long term strength [29-30] as shown by the "cross-over" effect of strength development of TMC and standard cured specimens. This "cross-over effect" was first reported by McIntosh [31]. The most significant improvement in strength for GGBS and PFA mixes appeared to be at around 3 days as compared to 1 day for PC mix. The difference in strength of TMC and standard $20^{\circ} \mathrm{C}$ cured specimens is shown in Figure 11. This is due to the pozzolanic reaction being slower than cement hydration and thus the delay in the peak temperature occurring at 3 days instead of 1 day as was for the PC mix [32-33]. There is no cross-over effect for GGBS50 and PFA50 mixes at 14 days. It appears however that this cross-over effect has simply been delayed to 28 days.

PC50 and PC30 strength development curves show similar trends (Figure 11a and Figure 11d, respectively), i.e. increased early age compressive strengths up to 14 days when the cross-over effect occurs.

The lower peak temperatures in walls and the lower duration of temperatures above ambient resulted in some beneficial effect to the early are strengths and these were only up to 3 days (see Figure 12). The short duration of the high temperatures does not seem to have caused the cross-over effect in the walls as it was seen in the blocks. 
The compressive strengths of TMC cubes are shown as a ratio with the strength of cubes cured at $20{ }^{\circ} \mathrm{C}$ in Figure 13. The beneficial effect of high "curing" temperatures for early age strength development of mixes with GGBS and PFA is obvious. Increased strengths are also obtained in walls although these are not as high as in blocks.

The strengths are also plotted in Figure 14 as a ratio of their 28 -day standard $20^{\circ} \mathrm{C}$ cured strength. The effect of high curing temperatures in blocks resulted in GGBS and PFA mixes achieving their 28-day strength from as early as 7-days. The detrimental effect of high early "curing" temperature on PC concrete can also be seen; the PC50 concrete did not achieve its 28-day strength. The higher than ambient temperatures in walls may have been beneficial to the early age strengths but not enough to raise them to their corresponding 28 -day standard $20^{\circ} \mathrm{C}$ cured strength values. 


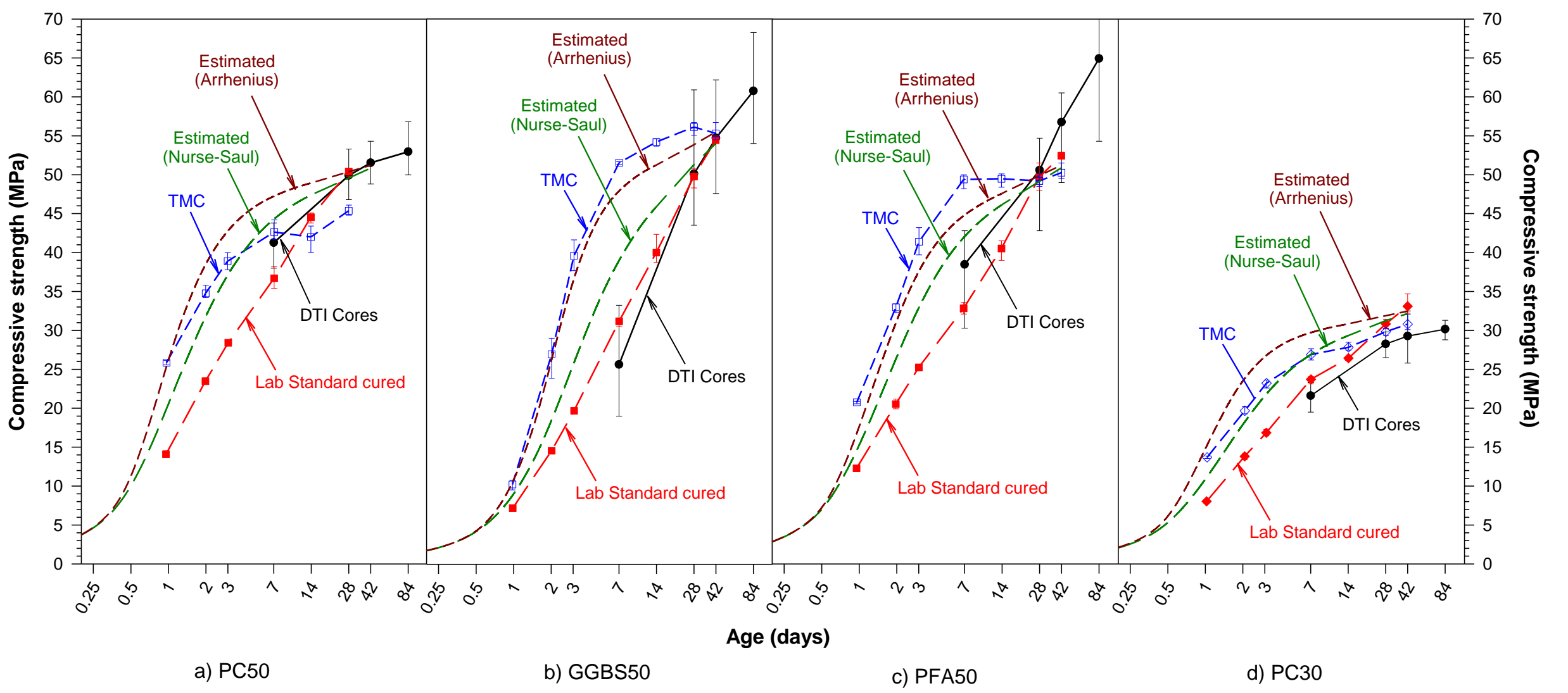

Figure 11: $\quad T M C$ strength development and in situ strength estimates for simulated summer blocks. 


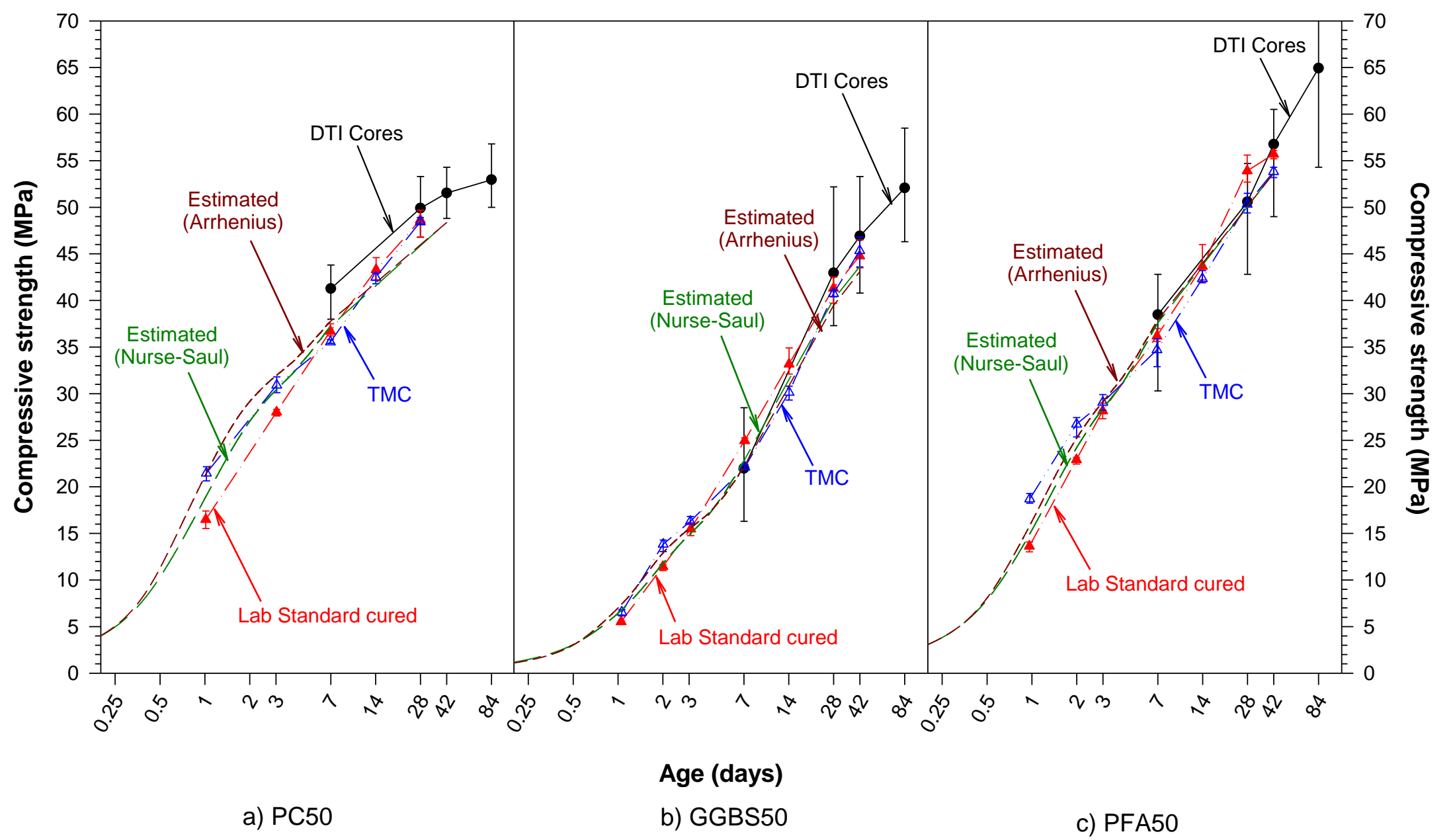

Figure 12: $\quad T M C$ strength development and in situ strength estimates for simulated summer walls. 


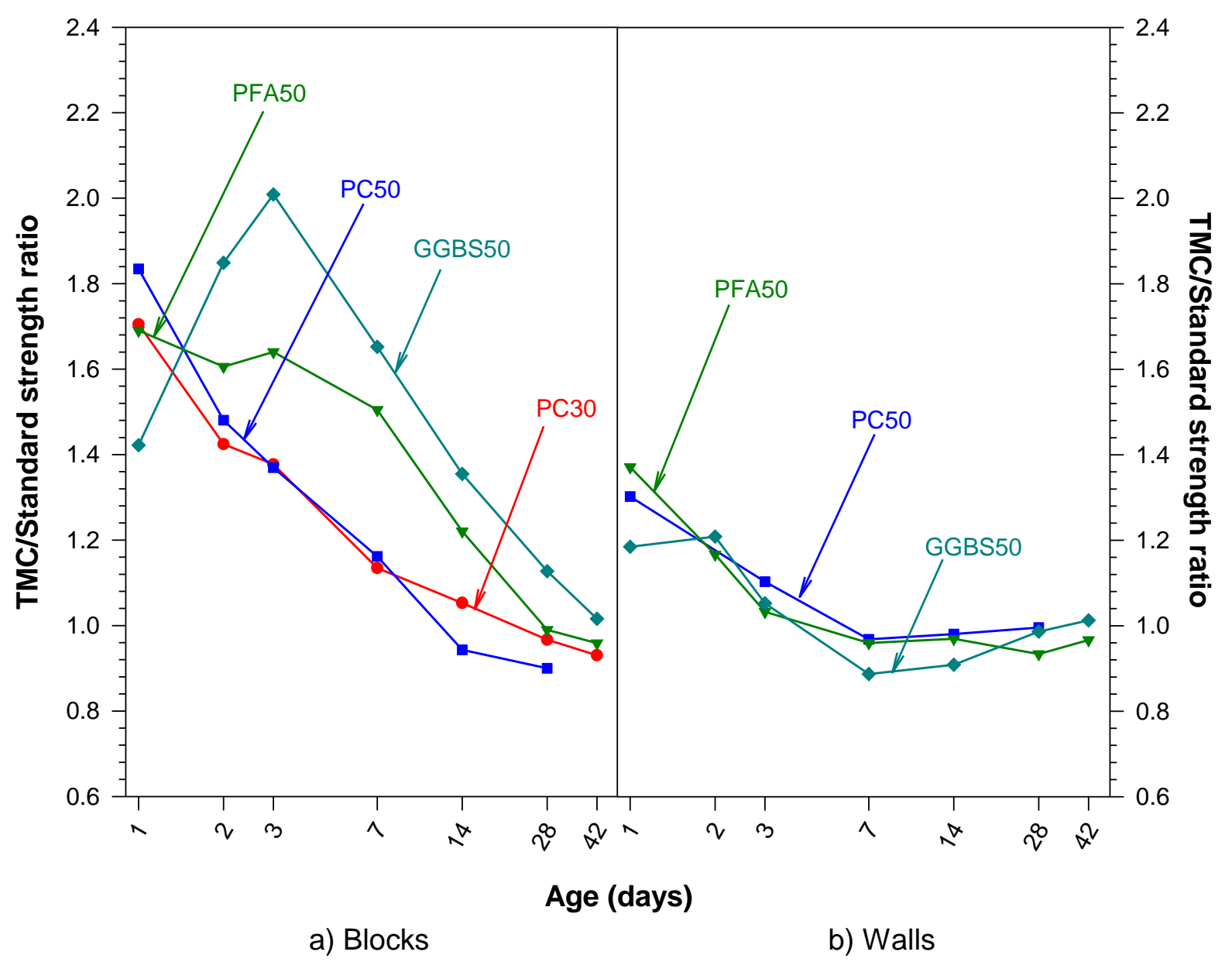

Figure 13: $\quad$ Strength ratio of TMC to standard cured concretes versus age. 


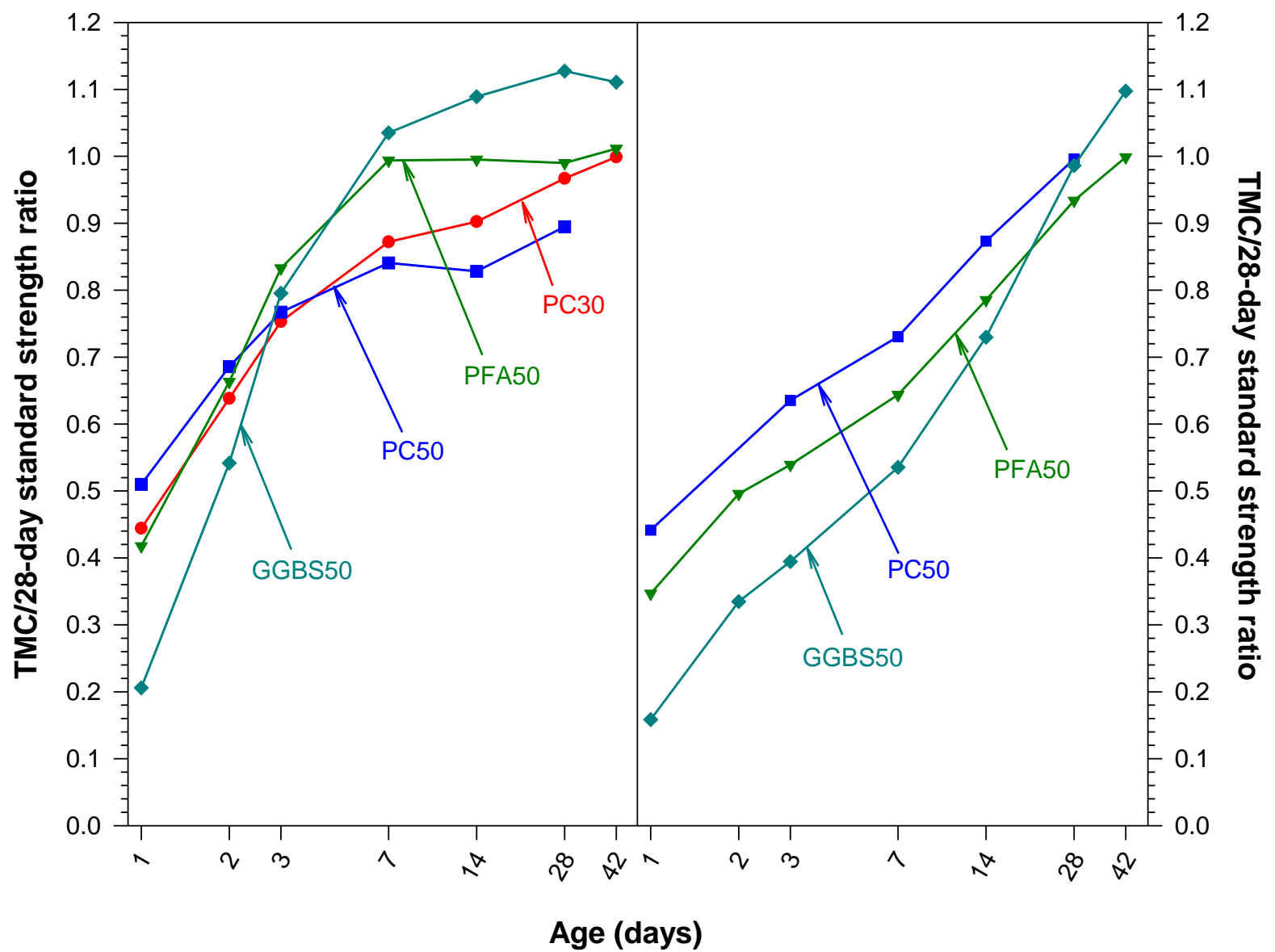

a) Blocks

b) Walls

Figure 14: $\quad$ Ratio of TMC strength to 28-day strength of standard cured concrete versus age.

\subsection{Applicability/accuracy of maturity functions for estimating the in situ strength development of mixes with SCMs}

Several maturity functions exist in the literature [10, 34-39], which estimate the strength development of concrete under elevated and variable temperature conditions from its temperature history. These models use the experimentally determined strength-age relationship at a reference temperature to estimate the strength at any other temperature. These models, however, were developed for Portland cement concrete. The temperature sensitivity of SCMs, particularly of GGBS, has been shown to be much greater, than Portland cement isothermally cured specimens $\left(20^{\circ} \mathrm{C}\right.$ to $\left.50{ }^{\circ} \mathrm{C}\right)$ [40-42]. It is therefore necessary to 
examine the applicability/accuracy of these maturity functions for concretes with SCMs, not only for isothermal curing, but also for temperature histories that are expected in situ.

The Nurse-Saul function requires the temperature history of the concrete in order to calculate the maturity index according to Equation 1. The maturity index obtained was then converted into an estimated strength using Figure 6(b). The Arrhenius function required the apparent activation energies of all six concretes which were previously determined [43] according to ASTM C1074 [21] method and they were PC30 = 37,382 J/mol, GGBS30 = 52,827 J/mol, PFA30 $=22,539 \mathrm{~J} / \mathrm{mol}$, PC50 $=29,698 \mathrm{~J} / \mathrm{mol}$, GGBS50 $=41,606 \mathrm{~J} / \mathrm{mol}$ and PFA50 $=27,309$ $\mathrm{J} / \mathrm{mol}$. These were found to be in good agreement with values in literature [41, 44-46]. The equivalent age $t_{e}$ at time $t$ was calculated using Equation 5. The specified reference temperature, $T_{s}$, used was $293{ }^{\circ} \mathrm{K}\left(20^{\circ} \mathrm{C}\right)$. $\mathrm{T}_{\mathrm{a}}$ being the average temperature, in Kelvin, of concrete during time interval $\Delta \mathrm{t}$ was the temperature history the concrete was subjected to (these were the temperature histories recorded from the blocks and walls on site). The value of equivalent age obtained, $t_{e}$, was then substituted for $t$ in Equation 4 with constants $S_{u}, k$ and $t_{0}$, as previously determined for the strength data obtained for the concrete cured at $20{ }^{\circ} \mathrm{C}$ (Table 5).

Table 5: Regression parameters (obtained from Eq. (4)) for $20^{\circ} \mathrm{C}$ strength development obtained using the ASTM method [21].

\begin{tabular}{|c|c|c|c|c|c|c|}
\hline Mix ID & PC30 & GGBS30 & PFA30 & PC50 & GGBS50 & PFA50 \\
\hline $\mathrm{S}_{\mathrm{u}}(\mathrm{MPa})$ & 33.36 & 36.91 & 46.35 & 55.49 & 55.7 & 63.93 \\
\hline $\mathrm{k}(1 / \mathrm{day})$ & 0.37 & 0.077 & 0.151 & 0.556 & 0.113 & 0.22 \\
\hline $\mathrm{t}_{0}$ (days) & $2.45 \mathrm{E}-01$ & $1.99 \mathrm{E}-01$ & $7.50 \mathrm{E}-09$ & $2.49 \mathrm{E}-09$ & $1.30 \mathrm{E}-09$ & $6.33 \mathrm{E}-09$ \\
\hline
\end{tabular}

Figure 11 compares the experimentally determined TMC strength developments of cubes with those estimated by the Nurse-Saul and Arrhenius functions for concretes cast in blocks.

The Arrhenius function estimates very well the 1-day strengths of the PC50 and PC30 concretes in the blocks. However, it overestimates strengths beyond 1-day and it deviates more from the actual TMC strengths with increasing age. This appears to be due to the 
inability of this function to account for the detrimental effect high early age temperatures have on later age strength.

The Nurse-Saul function underestimated the strength development at early ages, such as 1 to 3 days, and overestimated it at later ages. This suggests that the temperature dependence of the Nurse-Saul function is not sufficient to account for the improvement in early-age strength of concretes as a result of such high temperatures as were recorded in the blocks cast during summer. Similar trends have been noted for works done on isothermally cured specimens at $20,30,40$ and $50{ }^{\circ} \mathrm{C}[30]$.

Similar trends appear in the strength estimates of the GGBS50 and PFA50 TMC concretes. The Arrhenius function estimates relatively well the strength developments of these concretes. The strengths of these concretes at later ages, e.g., 28-days, are also estimated accurately since there was no cross-over effect prior to 28 -days. The Nurse-Saul function underestimates their strength development even more than it did for the PC50 concrete. This is because the Nurse-Saul function assumes that the concrete strength gain rate varies linearly with temperature. An exponential relationship, inherent in the "equivalent age" concept through the use of "apparent activation energies" would have been more appropriate.

Figure 12 compares the experimentally determined TMC strength developments of cubes with those estimated by the Nurse-Saul and Arrhenius functions for concretes cast in walls. The strength estimates are accurate but this is only because the lower temperatures in walls compared to blocks and shorter duration of temperatures above ambient did not have a significant effect on the strength. The strength increase of these mixes was not very significant even at 1 to 3 -days.

Figures 11 and 12 also show the strengths of concrete cores obtained from the blocks and walls. Core strengths obtained from blocks, see Figure 11, were lower than the TMC cube strengths at a particular age (less than 28 days) whilst they were similar for those from walls, see Figure 12. Some of the difference between core strength and TMC cube strength may be attributed to the effectiveness of onsite compaction. The densities of cores from the test elements were lower than the companion cube density - block density being $2.5 \%$ whilst only $1 \%$ for walls. This indicates that the larger volumes of concrete in the blocks were less well 
compacted than that in the walls. Core strengths continued to increase with age and this is more noticeable with the GGBSS and PFA mixes.

\section{Conclusions}

The continuous measurement of the in situ temperatures during the DTI concrete core project has made possible the determination of the effects of a range of environmental conditions and structural element parameters, including partial cement replacement with SCMs, on the early age temperature history and hence the strength development to be quantified. It was found that:

a. Mass concrete or near adiabatic conditions, i.e. small heat loss, accelerated the reaction of GGBS and PFA resulting only in small reductions in peak temperatures. However, the SMCs were effective in reducing the peak temperatures when there was heat dissipation.

b. High early age temperatures increase considerably the strength contribution of SCMs.

c. The Nurse-Saul function, based on the assumption that the rate of strength development is a linear function of temperature, underestimates the improvement in the early age strengths from such high temperatures as might occur in mass concrete. The Arrhenius based function assumes that the concrete strength gain rate varies exponentially with temperature and thus is able to estimate the early age strengths more accurately than the Nurse-Saul function.

\section{Acknowledgements}

The majority of the work described here was carried out by Dr A. Hatzitheodorou at the University of Liverpool as part of his $\mathrm{PhD}$ research. The authors are grateful to the School of Engineering, the University of Liverpool for the facilities provided and to the Engineering and Physical Sciences Research Council, UK (GR/R83880/01), for the financial support received for the equipment. The authors would like to thank Dr L.K.A. Sear at United Kingdom Quality Ash Association (UKQAA) for the extensive advice received during the project. 


\section{References}

1. British Standards Institution, "BS EN 12390-3:2002 - Testing hardened concrete. Compressive strength of test specimens", BSI, London, UK, 2002.

2. The Concrete Society, "In situ concrete strength. An investigation into the relationship between core strength and standard cube strength", Concrete Society Project Report No. 3, The Concrete Society, Crowthorne, UK, 2004, 55 pp.

3. The Concrete Society, "Concrete core testing for strength", The Concrete Society Technical Report No. 11, The Concrete Society, Crowthorne, UK, 1976, 44 pp.; republished with Addendum 1987.

4. Barnett, S.J., Soutsos, M.N., Bungey, J.H., and Millard, S.G., "Fast-Track Construction with Slag Cement Concrete: Adiabatic Strength Development and Strength Prediction", ACI Materials Journal, Vol. 104, No. 4, 2007, pp. 388-396.

5. Brooks, A.G., Schindler A.K. and Barnes R.W., "Maturity method evaluated for various cementitious materials", J. Mater. Civ. Eng. Vol. 19, Issue 12, 2007, pp. 1017-1025.

6. Galobardes, I., Cavalaro, S., Goodier, C.I., Austin, S. and Rueda, A., "Maturity method to predict the evolution of the properties of sprayed concrete", Construction and Building Materials, Vol. 79, 2015, pp. 357-369.

7. Sofi, M., Mendis, P.A. and Baweja, D., "Estimating early-age in situ strength development of concrete slabs", Construction and Building Materials, Vol. 29, 2012, pp. 659-666.

8. Yikici, T.A. and Chen, H., "Use of maturity method to estimate compressive strength of mass concrete", Construction and Building Materials, Vol. 95, 2015, pp. 802-812. 
9. Carino, N.J., “The Maturity Method”, In: Malhotra VM, Carino NJ, editors. Handbook on Nondestructive Testing of Concrete. 2nd ed. CRC Press; 2004, p. 5.1-5.47.

10. Saul, A.G.A., "Principles underlying the steam curing of concrete at atmospheric pressure", Magazine of Concrete Research, Vol. 2, No. 6, 1951, pp. 127-140.

11. Rastrup, E., "Heat of hydration in concrete", Magazine of Concrete Research, Vol. 6, No. 17, 1954, pp. 79-92.

12. Plowman, J.M., "Maturity and the strength of concrete", Magazine of Concrete Research, Vol. 8, No. 22, 1956, pp.13-22.

13. Nykanen, A., "Hardening of concrete at different temperatures, especially below the freezing point", In Proceedings of RILEM symposium on winter concreting, Session BII, Copenhagen: Danish Institute for Building Research, 1956.

14. Bernhardt, C.J., "Hardening of concrete at different temperatures", In Proceedings of RILEM symposium on winter concreting, Session BII, Copenhagen: Danish Institute for Building Research, 1956.

15. Carino, N.J., "Temperature effects on strength-maturity relation of mortar", NBSIR 81244, Gaithersburg, MD, USA: National Bureau of Standards; 1981.

16. Goral, M.L., "Empirical time-strength relations of concrete", Journal of the American Concrete Institute, Vol. 53, No. 8, 1956, pp. 215-224.

17. Chin, F.K., "Relation between strength and maturity of concrete", Journal of the American Concrete Institute, Vol. 68, No. 3, 1971, pp. 196-203.

18. Lew, H.S., and Reichard, T.W., "Prediction of strength of concrete from maturity", In: ACI SP-56 Accelerated Strength Testing, Ed. Malhotra V.M., Farmington Hills, MI, USA, American Concrete Institute, 1978, pp. 229-248. 
19. Freiesleben, H.P., and Pedersen, E.J., "Curing of concrete structures", CEB Information Bulletin 166; May 1985.

20. Carino, N.J., and Tank, R.C., "Maturity Functions for Concretes Made with Various Cements and Admixtures", ACI Material Journal, Vol. 89, No. 2, 1992, pp. 188-196.

21. ASTM International, "ASTM C1074-98 Standard practice for estimating concrete strength by the maturity method", In: Annual book of ASTM Standards, Vol. 04.02: Concrete and Aggregates, West Conshohocken, Pennsylvania, USA, ASTM International, 1999, pp. $540-547$.

22. British Standards Institution, "BS EN 197-1:2000 - Cement. Composition, specifications and conformity criteria for common cements", BSI, London, UK, 2000.

23. British Standards Institution, "BS EN 196-1-2005 - Methods of testing cement. Determination of strength”, BSI, London, UK, 2005.

24. British Standards Institution, "BS EN 15167-1:2006 - Ground granulated blast furnace slag for use in concrete, mortar and grout. Definitions, specifications and conformity criteria”, BSI, London, UK, 2006.

25. British Standards Institution, "BS EN 450-1:2005 - Fly ash for concrete. Definition, specifications and conformity criteria", BSI, London, UK, 2005.

26. British Standards Institution, "BS 882:1992 - "Specification for aggregates from natural sources for concrete", BSI, London, UK, 1992.

27. British Standards Institution, "BS EN 12350-2:2000 - Testing fresh concrete. Slump test", BSI, London, UK, 2000.

28. Teychenne, D. C., Franklin, R. E. and Erntroy H. C., "Design of normal concrete mixes”, BRE Press, $2^{\text {nd }}$ edition, 1997. 
29. Soutsos, M. N., Turu'allo, G., Owens, K., Kwasny, J., Barnett, S. J.; and Basheer, P. A. M., "Maturity Testing of Lightweight Self-Compacting and Vibrated Concretes", Construction and Building Materials, Vol. 47, 2013, pp. 118-125.

30. Soutsos, M.N., "The Effect of Temperature on the Rate of Strength Development of Mortar Mixes", Structural Faults \& Repair - 2010, 13th International Conference, Editor: Forde, M.C., Engineering Technics Press, 46 Cluny Gardens, Edinburgh EH10 6BN, UK, ISBN: 0-947644- 67-9, June 2010, p. 13.

31. McIntosh, J.D., "The effects of low-temperature curing on the compressive strength of concrete", In Proceedings of RILEM symposium on winter concreting, Session BII, Copenhagen: Danish Institute for Building Research, 1956.

32. Joshi, R.C. and Lohtia, R.P., "Fly ash in concrete", Overseas Publishers Association, 1997.

33. Pane, I. and Hansen, W., " Investigation of blended cement hydration by isothermal calorimetry and thermal analysis", Cement and Concrete Research, Vol. 35, Issue 6, 2005, pp. 1155-1164.

34. Babu, K.G. and Rao, G.S.N., "Early strength behaviour of fly ash concretes"; Cement and Concrete Research, Vol. 24, No. 2, 1994, pp. 277-284.

35. Kjellsen, K.O. and Detwiler, R.J., "Later-age strength prediction by a modified maturity model”, ACI Material Journal, Vol. 90, No. 3, 1993, pp. 220-227.

36. Abdel-Jawad, Y. A., "The maturity method: Modification to improve estimation of concrete strength at later ages", Construction and Building Materials, Vol. 20, 2006, pp. 893-900.

37. Chanvillard, G., D’Aloia, L., “Concrete strength estimation at early age: Modification of the method of equivalent age”, ACI Materials Journal, Vol. 94, No. 6, 1997, pp. 520-530. 
38. Parsons, T.J. and Naik, T.R., "Early age strength determination by maturity", Concrete International, Vol. 7, No. 2, 1985, pp. 37-43.

39. Liao, W-C., Lee, B. J. and Kang, C. W., “A humidity-adjusted maturity function for the early age strength prediction of concrete", Cement and Concrete Composites, Vol. 30, 2008, pp. 515-523.

40. Soutsos, M. N., Barnett, S. J., Millard, S. G., and Bungey, J. H., "The Effect of Temperature on the Rate of Strength Development of Slag Cement", ACI SP-263 Slag cement concrete, Aldea, C. M. (Editor), 2009, pp. 111-125.

41. Barnett, S.J., Soutsos, M.N., Millard, S.G., and Bungey, J.H., "Strength development of mortars containing ground granulated blast-furnace slag: Effect of curing temperature and determination of apparent activation energies", Cement and Concrete Research, Volume 36, Issue 3, 2006, pp. 434-440.

42. Boubekeur, T., Ezziane, K. and Kadri, E., "Estimation of martars compressive strength at different curing temperature by the maturity method", Construction and Building Materials, Vol. 71, 2014, pp. 299-307.

43. Hatzitheodorou A., "In-situ strength development of concretes with supplementary cementitious materials", PhD thesis, The University of Liverpool, 2007, pp. 241.

44. Poole, J.L., Riding, K.A., Juenger, M.C.G., Folliard, K.J. and Schindler, A.K., "Effects of supplementary cementitious materials on apparent activation energy", Journal of ASTM International, Vol. 7, No. 9, 2010.

45. Barnett, S.J., Soutsos, M.N., Millard, S.G., and Bungey, J.H., "Temperature Rise and Strength Development in Laboratory-Cast Structural Elements Containing Slag", American Concrete Institute SP-242: Ninth CANMET/ACI International Conference on Fly Ash, Silica Fume, Slag and Natural Pozzolans in Concrete, Warsaw, Poland, 2007, Ed. Malhotra, V. M., 
ISBN 978-0-87031-241-0, pp. 37-50.

46. Poole, J.L., Riding, K.A., Folliard, K.J., Juenger, M.C.G. and Schindler, A.K., "Methods for calculating apparent activation energy for Portland cement”, ACI Material Journal, Vol. 104, No. 1, 2007, pp. 303-311. 